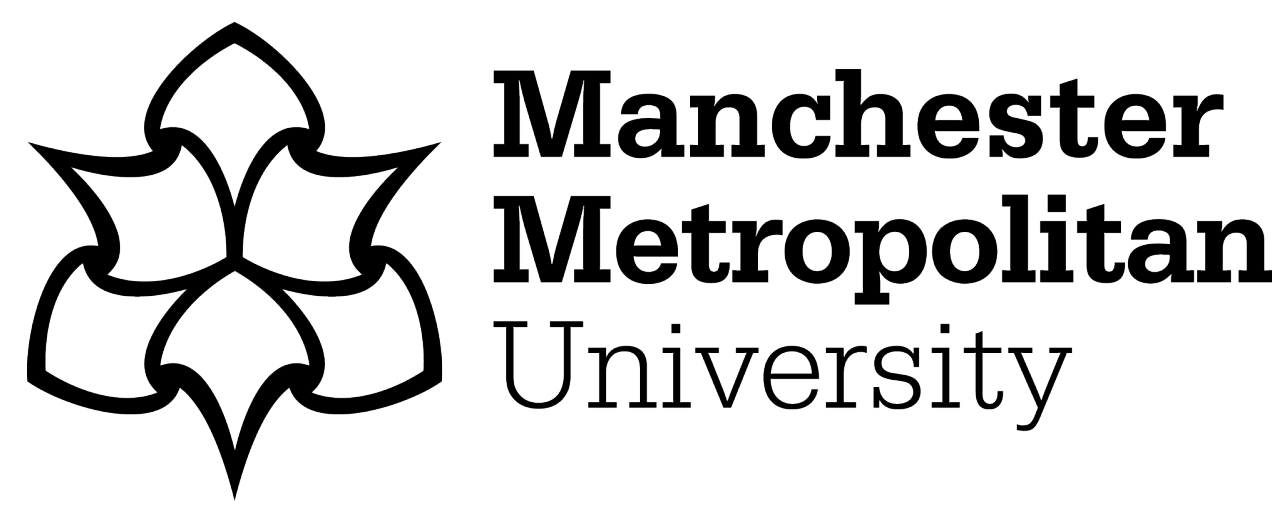

Golsorkhi, Soogand (2019) The Effect of Language Use on the Financial Performance of Microfinance Banks: Evidence From Cross-Border Activities in 74 Countries. Journal of World Business, 54 (3). pp. 213-229. ISSN 1090-9516

Downloaded from: https://e-space.mmu.ac.uk/622885/

Version: Accepted Version

Publisher: Elsevier

DOI: https://doi.org/10.1016/j.jwb.2019.03.002

Usage rights: Creative Commons: Attribution-Noncommercial-No Derivative Works 4.0

Please cite the published version 


\section{The Effect of Language Use on the Financial Performance of Microfinance Banks: Evidence from Cross-border Activities in 74 Countries}

\section{Sougand Golesorkhi* (*Corresponding author)}

Manchester Metropolitan University, Business School

All Saints Campus

Oxford Road, Manchester M15 6BH, UK

Phone (44) 1612473751

E-mail: s.golesorkhi@mmu.ac.uk

\section{Roy Mersland}

University of Agder

School of Business and Law

Gimlemoen, Postboks 422

N-4604 Kristiansand, Norway

Phone (47) 38141787

Fax (47) 38141028

E-mail: roy.mersland@uia.no

\section{Rebecca Piekkari}

Aalto University School of Business

Department of Management Studies

Runeberginkatu 14-16

00100 Helsinki, Finland

Tel: (+358) 503837380

Fax: (+358) 94708880

E-mail: rebecca.piekkari@aalto.fi

\section{Grigory Pishchulov}

Alliance Manchester Business School

The University of Manchester

Booth Street West

Manchester M15 6PB, UK

and

St. Petersburg State University

7/9 Universitetskaya nab.

St. Petersburg, 199034 Russia

E-mail: grigory.pishchulov@manchester.ac.uk

\section{Trond Randøy}

University of Agder

School of Business and Law

Gimlemoen, Postboks 422

N-4604 Kristiansand, Norway

Phone (47) 38141525

Fax (47) 38141028

E-mail: trond.randoy@uia.no 


\title{
The Effect of Language Use on the Financial Performance of Microfinance Banks: Evidence from Cross-border Activities in 74 Countries
}

\begin{abstract}
This multi-year study examines the relationship between financial performance and language use, observing 405 partnerships between microfinance banks and their international financial partners in 74 countries. Drawing on language research in international business, we find that microfinance banks based in English-speaking, French-speaking, and Spanish-speaking countries have higher performance. Furthermore, the linguistic distance between the home country of a microfinance bank and the home country of its international partner(s) is negatively related to its financial performance. Our large-scale study confirms the effect of language use on organization-level financial performance and extends research on language in multinationals from intra-firm to inter-firm relationships.
\end{abstract}

Keywords: language in business, English, French, Spanish, microfinance, inter-firm international partnership, firm performance 


\section{Introduction}

A study commissioned by the UK government shows that lack of foreign-language proficiency is estimated to cost the economy 3.5\% of its GDP (Foreman-Peck \& Wang, 2014). These language-driven costs are hard to estimate, because firms typically cover a substantial share of them in the form of missed business opportunities or miscommunications (CILT, 2006). We argue that the global microfinance industry is a context in which the effects of language use on organization-level financial performance can be captured empirically. In this highly international industry, language is a salient characteristic of cross-border partnerships.

In this paper, we study the language-infused relationship between international financial partners (such as lenders, donors, and investors) and microfinance banks (MFBs). ${ }^{1}$ Such banks provide banking services like credit, savings, and insurance to micro-entrepreneurs and local households in a financially sustainable manner (Morduch, 1999). MFBs often operate in low-income countries with limited ability to communicate for professional purposes in one of the global languages such as English, Spanish, or French. Language-skilled university graduates are not attracted to MFBs because they perceive microfinance as a low-paying banking industry with low prestige (Access-Assist, 2014). This makes it difficult to hire staff with requisite language skills to communicate with international financial partners, who are based in high-income countries such as North America and Europe and who are separated from MFBs by a large linguistic distance. Yet, in order to deliver banking services, MFBs need to communicate with these partners because they provide access to capital, knowledge, and other resources.

Microfinance represents a particularly relevant context for studying language effects on financial performance for several reasons. International donors (e.g., the Melinda and Bill Gates Foundation), regulatory authorities, and international agencies (e.g., the World Bank) collectively push for global transparency that ensures that detailed performance information about MFBs is available. This

\footnotetext{
${ }^{1}$ Providers of financial services to low-income people and their income-generating activities are often termed microfinance institutions (MFIs). In this paper, we call them microfinance banks (MFBs) because the nature of their activities is similar to that of banks even though only some of them are regulated by national banking authorities.
} 
information would be inaccessible in most other industries, particularly in emerging markets (Beisland, Mersland, \& Randøy, 2014). As one of the world's largest banking markets in terms of number of customers served, ${ }^{2}$ the industry is highly dependent on standardized written manuals, handbooks, and codes of practice. The Consultative Group to Assist the Poor (CGAP), a microfinance branch of the World Bank, plays an important role in producing these documents primarily in English, but also in other global languages such as French and Spanish. These languages enjoy the status of the official or "semi-official" language in many Latin American and African countries and they are used in strategic domains of society, such as government, law courts, mass media, business and the educational system (Crystal, 2003; Simons \& Fennig, 2018). An additional reason for our choice of industry stems from our own extensive experience ${ }^{3}$ in microfinance. We have witnessed how suboptimal language practices can persist in this industry for a long time. International financial partnerships within the microfinance industry are typically not under the same competitive pressure to be terminated as relationships between regular commercial firms because there is no take-over market for underperforming MFBs (hardly any of them are publicly listed). Neither is the performance of MFBs affected by ownership type, or their for-profit versus non-profit status (Mersland \& Strøm, 2009), indicating that also MFBs with non-profit status focus on long-term financial sustainability. Thus, the microfinance industry is almost like a natural "laboratory," exhibiting an extreme case (Yin, 2014) in which we can disentangle the distinct effects of language use on the financial performance of MFBs.

To the best of our knowledge, research on whether and how language matters for the financial performance of organizations is yet to be undertaken. ${ }^{4}$ Scholars have investigated the performance effects of language use in conceptual terms (Luo \& Shenkar, 2006) or in empirical terms by studying how key factors such as effectiveness of communication (Harzing \& Pudelko, 2014), knowledge flows (Mäkelä, Kalla, \& Piekkari, 2007; Reiche, Harzing, \& Pudelko, 2015), and language-sensitive

\footnotetext{
${ }^{2}$ Reed (2013) reports that MFBs reach 200 million families with credit services and Lloyd's (2012) estimates that 1 billion people will hold a micro-insurance policy within the next ten years.

${ }^{3}$ Two of the co-authors of this study have 25 and 10 years of experience, respectively, having held various management and board positions in the microfinance industry.

${ }^{4}$ Given that many MFBs are not profit maximizing, we have also applied other performance measures such as operational self-sufficiency (OSS) in this study. The OSS measures whether operating income covers operating costs, financial costs, and provisions for loan defaults.
} 
recruitment (Peltokorpi \& Vaara, 2014) have indirect implications for organization-level financial performance. Researchers have also suggested that "soft" skills such as culture and language may have "hard" performance outcomes (Brannen, Piekkari, \& Tietze, 2014; Piekkari, Welch, \& Welch, 2014), although large-sample empirical evidence is still limited. We respond to this call, as much of the previous language research in IB is qualitative in nature (Tenzer, Terjesen, \& Harzing, 2017). Furthermore, much of the research has focused on language within multinational corporations (MNCs) (Brannen et al., 2014) rather than on inter-firm partnerships (e.g., Boussebaa, Sinha, \& Gabriel, 2014; Cuypers, Ertug, \& Hennart, 2015; Joshi \& Lahiri, 2015). We address these research gaps by exploring the effect of language use on organization-level financial performance, based on panel data on 405 partnerships between MFBs and their international financial partners in 74 countries.

The contribution of the present study to the research on language in international business is fourfold. First, by using large-scale, multi-year, multi-country panel data we empirically confirm the effect of language use on the financial performance of microfinance banks. Much of the existing research focuses on initial international expansion, exporting, and foreign market entry (Crick, 1999; Hurmerinta, Nummela, \& Paavilainen-Mäntymäki, 2015; Leonidou, 1995; Lopez-Duarte \& Vidal-Suárez, 2010) rather than on the more long-term effects of language on firm survival and performance. Furthermore, we specify which languages matter for the financial performance of the firm, as the existing research primarily considers the role of English without comparing it to other languages (e.g., Boussebaa et al., 2014; Cuypers et al., 2015). Our findings indicate that English is the most effective global language in the microfinance industry, although we also see positive effects in the use of Spanish and French. Second, we address language use in inter-firm relationships (between the MFB and its main international financial partners), whereas the existing research mostly focuses on intra-firm headquarters-subsidiary relationships. Specifically, we argue that from a language perspective, interfirm relationships differ from intra-firm relationships due to variations in resource access, contractual relationships, and governance practices. Third, we investigate language in the context of microfinance as a global service industry. Much of the existing language research focuses on manufacturing rather than the service sector. Yet, we know that the delivery of services is highly language-dependent (Holmqvist, 2009; Holmqvist, Van Vaerenbergh, \& Grönroos, 2017) and this issue is particularly salient 
in the case of MFBs. While interaction with clients in emerging markets is locally embedded (Bruton, Khavul, \& Chavez, 2011) and necessitates mastery of local languages and dialects, successful interaction with international financial partners depends on the MFB's ability to use a global language to access capital, knowledge, and best practices. Ultimately, the interaction with these international partners determines the quality of services provided to local borrowers. Fourth, our focus on emerging, low-income markets enriches the existing research on language in international business, which is conducted predominantly from the perspective of developed markets such as the UK, USA, Finland, Germany, Japan, and Sweden (Tenzer et al., 2017). Emerging markets often have several official languages due to their colonial past, rendering them a highly rich language environment. Furthermore, the value of language skills is extremely high in emerging countries where the level of education and the general proficiency in English, or any other global language, tend to be low.

In the next section, we first describe our research context of the microfinance industry and the type of international partnerships that characterize this industry. This is followed by our theoretical underpinnings and the development of hypotheses. The remaining sections outline the methodology, operationalization of key variables, and empirical results. The paper concludes with a discussion of our key findings and suggestions for future research.

\section{International financial partnerships in the microfinance industry}

Present-day microfinance began as a local philanthropic development effort in the 1970s with Bangladeshi Mohammad Yunus, winner of the Nobel Peace Prize in 2006, as the best-known pioneer. International financial partnerships, which are largely based on contractual agreements, are more the norm than the exception among MFBs. A global survey shows that $38 \%$ of MFBs have a foreign initiator, $41 \%$ have international commercial debt, $51 \%$ have foreign subsidized debt, $24 \%$ have at least one foreign director, and 33\% are members of a formal international network (Mersland, Randøy, \& Strøm, 2011). These numbers suggest that microfinance is a highly international banking industry in which international financial partnerships with MFBs play a key role.

Figure 1 shows a typical partnership in the microfinance industry, which is very different from the equity-based headquarters-subsidiary relationships that have dominated language research in 
international business. The first half of the language dyad is the MFB based in a low-income country in the "South". MFBs can legally be banks or other types of financial institutions regulated by national banking authorities, or they can be organized as member-based cooperatives or NGOs (Mersland, 2009). As Figure 1 illustrates, international financial partners represent the second half of the language dyad. They are based in high-income countries in the "North" (though in some cases we observe Southto-South collaborations as well, e.g., Bangladeshi-based BRAC entering African countries like Liberia and Uganda). International financial partners include development-motivated international nongovernmental organizations (NGOs), investment funds, and so-called microfinance investment vehicles (MIVs). Based on contractual agreements, these partners provide MFBs with technical assistance, network access, funding, and sometimes ownership ties and are often actively involved in the start-up phase of the MFB regardless of ownership type. Not only are MFBs in the South "reaching out" to the North to form partnerships, but also organizations in the North, such as international "impact lenders," are turning to the South in search of attractive partners (Hummels \& Millone, 2014). In fact, international funding is one of the main innovations that makes microfinance different from other poverty-lending models (Mersland \& Strøm, 2012).

Insert Figure 1 about here

Our study focuses on dyadic relationships between MFBs and their international financial partners rather than on multiple relationships between MFBs and local stakeholders (see Figure 1). MFBs are typically separated from their international financial partners by a great (geographical, cultural, economic, and linguistic) distance. MFBs based in low-income countries often struggle to access skilled labor and sophisticated funding and market knowledge locally, particularly in rural markets. For them, accumulation of in-house funding and market knowledge becomes critical, but it often requires proficiency in a global language. Knowledge creation and sharing in a global service industry such as microfinance have been high on the agenda of policy-makers for decades (e.g., CGAP of the World Bank). In addition, there are other international knowledge-sharing initiatives such as the Microfinance Gateway (www.microfinancegateway.org), an online donor-funded library. Another such initiative is 
Mixmarket (www.mixmarket.org), a web platform that helps to match MFBs with international lenders, networks, and service providers. As Figure 1 suggests, the flows of knowledge, capital, and other resources from international financial partners in the high-income North to the MFB in the low-income South are language-dependent and thus affect the performance of the partnership.

The question of how to define and measure performance in the context of the microfinance industry has been debated extensively (Bruton et al., 2011). While there have been high hopes that microlending would alleviate poverty in terms of, e.g., increased employment and empowerment of women, the evidence is still limited. Banerjee, Karlan, \& Zimman (2015, p. 1) summarize its impact as "a consistent pattern of modestly positive, but not transformative effects." Guérin and Kumar (2017) conclude that contrary to common belief, access to microfinance does not always empower women. Furthermore, critics point out its negative side effects, such as predatory lending with exceptionally high interest rates (Hudon \& Sandberg, 2013). Thus, "the business of doing good" is not straightforward and the debate on how to measure and evaluate the performance of MFBs has been going on for the past two decades (Armendáriz \& Morduch, 2010). Nevertheless, as indicated by Mersland and Strøm (2010), "sufficient" financial performance is a prerequisite for the successful, long-term operation of MFBs. To sum up, language affects the organization-level financial performance of MFBs in low-income countries in terms of financial as well as social returns, but we focus on the organizational-level financial performance.

\section{Theory and hypotheses}

As discussed in the previous section, international partnerships in the microfinance industry more closely resemble contractual alliances between external parties than equity-based internal headquarterssubsidiary relationships in MNCs, which have been the focus of much of the language research in international business (Piekkari et al., 2014). The nature of these contractual agreements, lack of local resources (capital, knowledge, and language), and governance and ownership structures limit the ability of MFBs to deal with language issues. Yet, the stream of research on headquarters-subsidiary relationships in MNCs provides a useful starting point for us: it suggests that language influences managerial decisions and ultimately financial performance (Brannen et al., 2014), even if hard-core 
evidence to establish this relationship is still lacking. The study by Monteiro, Arvidsson, and Birkinshaw (2008) is a step in this direction. They found that the poorly performing subsidiaries did not have access to "best practices" and were not included in internal networks that could provide them with timely information. While these authors did not focus on language use per se, their study points to the detrimental consequences of limited language skills for foreign subsidiary performance. As Luo and Shenkar (2006, p. 324) explain in conceptual terms, "[g]lobal language design affects corporate performance via several channels," such as communication, coordination, knowledge sharing, and value creation.

The literature on international alliances and joint ventures is only beginning to consider language issues (Brannen \& Salk, 2000; Liu, Adair, \& Bello, 2015; Joshi \& Lahiri, 2015). What emerges from this body of research is that language use is central to the performance of international partnerships since partners provide and receive capital, expertise, and other resources through acts of communication. In this stream of research, language takes on primarily two meanings: a national language that is closely linked to the national culture of each alliance partner (e.g., Brannen \& Salk, 2000; Cuypers et al., 2015; Drori, Manos, Santacreu-Vasut, Shenkar, \& Shoham, 2018) and language as a communicative resource that is used in the interaction between partners (Liu et al., 2015). Communicative resources are not limited to language but include also "the non-verbal, visual, symbolic, and material" (Karhunen et al, 2018, p. 1000). These two approaches to language can also be combined (e.g., Joshi \& Lahiri, 2015).

In international business research, the relationship between language and national culture has attracted attention (Tenzer et al., 2017). During the 1960s and 1970s, early writers in international business drew heavily on Edward T. Hall's (1959) work on culture, and for many years language was subsumed under the concept of culture (Piekkari \& Westney, 2017). In more recent research, however, language has been recognized as a separate construct worthy of attention in its own right (Brannen et al., 2014; Brannen \& Mughan, 2017). While we recognize that language is the defining feature of many cultures, in this paper we adopt the position that language is analytically distinct from culture. This approach is well aligned with our focus on the use of global languages.

Research on international joint ventures and inter-firm relationships differentiates the national 
language of the parent company and the language of the joint venture or the target (Brannen \& Salk, 2000). Brannen and Salk (2000) used mixed methods to study a German-Japanese joint venture. English, the official language of the international joint venture, was the mother tongue of neither the Japanese nor the Germans, and "a lot of difficulties arose from the lack of a shared language" in the daily negotiations between managers who were running the venture (Brannen \& Salk, 2000, p. 474). These authors conceptualized language as an organization-level factor specific to the joint venture in question. Cuypers et al. (2015) investigated in a large quantitative study the effects of linguistic distance and proficiency in a shared language on ownership structure. Their findings show that acquirers take lower equity stakes in foreign targets when linguistic distance and differences in English language proficiency are high. As in our study, they also viewed language as a country-level factor.

The second approach to language is to treat it as a communicative resource. Research in strategic management acknowledges that "the language managers use profoundly influences their perceptions of the world around them and thus the strategic options their firm might consider" (Brannen \& Doz, 2012, p. 80). In this regard, international partners may be separated from the MFB by a "discursive void" (Tietze, Tansley, \& Helienek, 2017, p. 152), where one party uses a contextually specific corporate language while the other party uses a conceptually abstract language (Brannen \& Doz, 2012). Liu et al. (2015) studied the operation and performance of international joint ventures and found that partners who share relational metaphors and are linguistically matched have superior outcomes. Joshi and Lahiri (2015) combined the two approaches to language (i.e., as national language and as communicative resource) and found that language friction, which occurs when two parties engage in abstract reasoning and problem solving using different native tongues, affects selection of alliance partners. They identified an inverted U-shaped relationship whereby little language friction may enhance alliance formation by MNCs, while excessive friction may prevent collaboration. In our study, we approach language as a country-level construct rather than as one specific to the MFB in question.

\subsection{Hypothesis development}

In this section, we suggest a stepwise development of hypotheses to test the effect of language use on the organization-level financial performance of the MFB. We first predict the language effect on a more 
general level (H1) and then propose hypotheses on the level of dyadic partnerships (H2 and H3).

We argue that the use of a global language provides the MFB with access to critical resources, best practices, and timely information. A key question then is which languages serve as global languages in the microfinance industry. There are about 7,000 languages (Lewis, Simons, \& Fennig, 2016) but only a few serve as global languages. A language achieves a genuinely global status when its special role is widely recognized (Crystal, 2003, p. 3). The global status of a language is often measured in terms of the number of countries in which this language enjoys the status of an official language; i.e., it is used in strategically important domains of society, such as government, law courts, mass media, business, and the educational system (Crystal, 2003; Simons \& Fennig, 2018). Today, English is the official national language in more than 80 countries (Simons \& Fennig, 2018). No other language - not French, German, Spanish, Russian, Arabic, or Mandarin Chinese - enjoys such an undisputable status in the world. By comparison, Spanish is the official national language in 21 countries and French in 39 (Simons \& Fennig, 2018). The global status of English can also be justified by the number of native speakers or foreign-language learners (Crystal, 2003).

For the purposes of our study of microfinance, English, French, and Spanish are the global languages that matter due to the colonial past of many international partnerships between low- and high-income countries. The largest market for microfinance is in Latin America, where Spanish is widely spoken. In Africa, English and French are generally used to transcend indigenous languages and achieve national cohesion between diverse ethnic groups. For example, both Zaire and Guinea are multilingual countries, but French enjoys the status of an official language (Swift, 1993). These emerging markets represent a rich environment consisting of unique indigenous languages as well as local varieties of global languages in terms of pronunciation, vocabulary, and grammar.

English has established itself as the lingua franca of the international finance and banking industry (Sanden, 2015). The dominance of English is evident in the number of microfinance-related documents that the Microfinance Gateway library provides to MFBs and their international partners. The library offers access to key documents, of which 8,341 are written in English, 1,258 in French, 1,052 in 
Spanish, and a few in other languages. ${ }^{5}$ Since MFBs in low-income countries lack state-of-the-art knowledge and best practices of the industry locally, they become dependent on these resources that are available primarily in one of the global languages. Therefore, we posit that a global language is instrumental in enabling MFBs to access critical resources and timely information. Thus, we expect that:

H1: MFBs based in countries in which a global language holds an official status have better financial performance than MFBs located in countries with other official languages.

In our stepwise development of hypotheses, we now proceed to the level of dyadic partnerships and argue that the ability of the MFB to engage in a meaningful business dialogue with international financial partners is premised on a shared language, whether English or another language. If the MFB does not have the requisite language skills its ability to communicate with external parties such as international lenders, donors, and technical assistants will be limited. Similarly, the access of the MFB to state-of-the-art research, competencies, and best practices of the industry about bank-customer relationships, internal auditing practices, and IT systems becomes restrained because this information is available mostly through international conferences, journals, blogs, and the web, but not locally. Overall, the MFB gains hardly any benefits from its memberships in international partnerships if the local managers and board members cannot communicate across borders. Thus, a shared language allows partners to establish a common ground and build organizational routines that facilitate collaboration and enable the effective management of their venture (e.g., Zollo, Reuer, \& Singh, 2002). Such routines include patterns of action for joint problem solving, contractual compliance, and intellectual property sharing (Heimeriks \& Duysters, 2007; Heimeriks, Klijn, \& Reuer, 2009). A shared language contributes to the development of these routines and improves the ability of partners to exchange timely and relevant knowledge concerning, e.g., technological developments. Ultimately, the interaction of the MFB with international financial partners affects its ability to use the latest knowledge in serving local borrowers and improves its performance. Hence, we hypothesize that:

\footnotetext{
${ }^{5}$ www.microfinancegateway.org, retrieved May 2016.
} 
H2: MFBs based in countries that share a global language with the country of their international financial partners have better financial performance than those MFBs that do not share such a global language.

We posit that the linguistic distance between the MFB and its international financial partners has a negative effect on the MFB's financial performance. The notion of linguistic distance is central to our study and has been discussed in the context of both intra- and inter-firm relationships. Starting from intra-firm relationships between headquarters and subsidiaries, since the late 1990s a number of empirical studies have emerged from Northern Europe exploring how language affects the internal functioning of the internationalizing firm (Andersen \& Rasmussen, 2004; Barner-Rasmussen, 2003; Fredriksson, Barner-Rasmussen, \& Piekkari, 2006; Marschan, Welch, \& Welch, 1997; MarschanPiekkari, Welch, \& Welch, 1999a, 1999b). For example, Marschan-Piekkari et al. (1999a, p. 435) showed that subsidiary staff's lack of fluency in the company language and the parent-country language created a sense of distance and disconnectedness from headquarters. Similarly, Slangen (2011, p. 1702) identifies linguistic barriers that generate costs and "complicate, impede, or slow down the process of transmitting verbal messages" between MNC parents and prospective subsidiaries.

Linguistic distance between international financial partners has parallels with the notion of psychic distance identified in research on the internationalization process of the firm. Johanson and Wiedersheim-Paul (1975) viewed language as one of the key factors driving psychic distance between countries, preventing information about the foreign market from reaching organizational decision makers at headquarters (Dow \& Karunaratna, 2006; Håkanson, Ambos, Schuster, \& Leicht-Deobald, 2016). The measure of psychic distance has been extensively used to explain internationalization patterns of companies originating from various countries. This research has shown that managers are drawn to markets that endorse a short psychic distance, because it reduces the extent and cost of adjustments that have to be made to ensure marketing effectiveness (Crick, 1999; Hagen, 1999; Holden, 1998; Leonidou, 1995; MacDonald \& Cook, 1998; Mughan, 1990; Swift, 1991).

Cuypers et al. (2015) investigated language in inter-firm relationships in the context of cross-border acquisitions. They found that linguistic distance has a negative effect on the equity taken by acquirers 
because it makes it more difficult for acquirers to access tacit information. Cuypers et al. (2015, p. 431) argued that "differences in languages are important reasons why information is not transferred, and hence why there is information asymmetry" in inter-firm relationships. They also posited that linguistic distance remains relevant even though a growing percentage of business transactions are conducted in English. In their concluding remarks, Cuypers et al. (2015, p. 440) speculated that "[s]ituations of information asymmetry also arise in the context of investing and financing, so the ability to access international sources of capital should be negatively affected by linguistic distance and low lingua franca fluency." We argue that the consequences of linguistic distance permeate a number of inter-firm transactions, thus affecting negatively the financial performance of the MFB. Hence, we propose that:

H3: MFBs that are at a greater linguistic distance from their international financial partners have worse performance than MFBs at a smaller linguistic distance.

\section{Methods}

Much of the existing research on language in IB is qualitative in nature and there is a clear "need for more large-scale studies covering [...] a wide variety of country contexts in order to probe the generalizability of the impact of foreign language use" (Tenzer et al., 2017, p. 836). In fact, during the past five years there has been an increase in the number of quantitative studies on this topic, reflecting the general state of this field of study. For the purposes of this study, we group quantitative language research in IB into four overlapping categories: knowledge flows and transfer (e.g., Peltokorpi, 2015; Peltokorpi \& Vaara, 2014; Reiche et al., 2015; Schomaker \& Zaheer, 2014); communication, coordination, and control (e.g., Barner-Rasmussen, Ehrnrooth, Koveshnikov, \& Mäkelä, 2014; Björkman \& Piekkari, 2009; Harzing \& Pudelko, 2013; 2014; Jeanjean, Stolowy, Erkens, \& Yohn, 2015; Lauring \& Selmer, 2013; Swift \& Wallace, 2011), expatriate management (e.g., Fan, Cregan, Harzing, \& Kohler, 2018; Freeman \& Olson-Buchanan, 2013; Ishii, 2012; Selmer, 2006; Wang, 2012); and cross-border acquisitions and alliances (e.g., Cuypers, Ertug, \& Hennart, 2015; Dow, Cuypers, \& Ertug, 2016; Joshi \& Lahiri, 2015; Kedia \& Reddy, 2016). Our study of the effect of language use on the organizational-level financial performance of microfinance banks can be placed under the last heading. 


\subsection{Data}

The dataset consists of 405 rated MFBs (unit of analysis) from 74 countries. The rating reports come from the five leading rating agencies specializing in microfinance: MicroRate, Microfinanza, Planet Rating, Crisil, and M-Cril. The decision of an MFB to obtain a rating from an international rating agency indicates some form of international orientation since a rating is often needed when accessing funders or seeking other types of international partners. In this regard, it can be argued that the dataset has a certain sample selection bias, since only rated MFBs are included. However, in practice, MFBs interested in accessing cross-border partnerships and funding need to present an external rating report as a prerequisite for entering into negotiation. This applies in particular to younger MFBs with the need to gain an international reputation. It has also become a necessity for MFBs with international pretensions to present their profiles at www.mixmarket.org. In order to get a full transparency score (5 diamonds) on this web platform, they need to include an external rating report.

Our dataset thus represents internationally oriented MFBs that have the intention to practice microfinance in a business-oriented and transparent manner. Moreover, our data on rated MFBs have some distinct advantages over data obtained from other widely used MFB databases (e.g., www.mixmarket.org). First, our data contain important information, e.g., on international initiators and network memberships, unavailable from other sources. Second, our data are not self-reported by firms as in the Mixmarket database; instead, our data were collected and verified by a third party, the rating agency (Beisland \& Mersland, 2012). Third, our data contain information on a mix of small and large MFBs, whereas Mixmarket data contain relatively more of the very large MFBs that are rated by traditional agencies such as Standard \& Poor's, rather than microfinance-specific rating agencies.

We consider our data robust because comparisons of the methodologies used by the five abovementioned rating agencies do not reveal any major differences from the methodology we use in our study. The five rating agencies differ in emphasis and availability of information. Thus, there are different numbers of observations across the variables and the reported years. To be able to combine the various rating methodologies, we annualize and measure in US dollars the data entries using the official exchange rates at the time. The rating reports, representing the basis for the database we constructed, extend from 1999 to 2009. The dataset is an extended, up-to-date version of a dataset used 
in several prior studies (Randøy, Strøm, \& Mersland, 2015; Galema, Lensink, \& Mersland, 2012; Mersland et al., 2011; Mersland \& Strøm, 2009).

In addition, we employ random effect estimations under the assumption that the unobserved heterogeneity error term is uncorrelated with each independent variable. Testing for shared bias method as a source of endogeneity, we observe that Harman's one factor test reveals no underlying scales or structure among variables (Sharma, Yetton, \& Crawford, 2009).

For each MFB, we identify by a dummy variable whether international financial partners are initiators, directors, network members, or debt providers, in accordance with the availability of the data (see Appendix A for the descriptive statistics on MFBs' international partner types). A number of legal and organizational forms are present in our dataset; however, all MFBs are either non-governmental organizations (NGOs), member-based cooperatives, or shareholder-controlled firms with various degrees of profit motivation. Using a dataset of rated MFBs ensures that only internationally and professionally oriented MFBs are included. We do not include other microfinance providers, such as government banks, small savings and credit cooperatives, and development programs that offer microcredit solely for welfare.

\subsection{Dependent variable}

We measure MFBs' financial performance (dependent variable) in terms of real, inflation-adjusted return on assets (ROA). ROA is our main indicator of financial performance because it "summarizes" an MFB's financial success and has been used in prior studies (Mersland et al., 2011; Cull, DemirgûçKunt, \& Morduch, 2007; Hartarska, 2005). Since MFBs differ greatly in their debt-to-equity ratios and since they may have different profit orientations, ROA is a better indicator of the financial performance of an MFB than the traditionally used return on equity (ROE) indicator (Mersland \& Strøm, 2009). ${ }^{6}$ Specifically, the ROE indicator is subject to limitations as it is sensitive to capital structure, and capital structure preferences can be associated with different ownership forms (such as for-profit, non-profits, or cooperatives).

\footnotetext{
${ }^{6} \mathrm{We}$ have performed an additional robustness test with ROE (return on equity at the end of a given period) as the dependent variable and the test results do not deviate substantially from the ROA results of this study.
} 
Most MFBs operate with a "double bottom-line" approach that values social returns as well as financial returns (Armendáriz \& Morduch, 2010). Nevertheless, as indicated by Mersland and Strøm (2010), the main struggle of MFBs is to keep operational costs down in order to enhance financial performance. These authors suggest that MFBs with good financial performance can use this to enhance their social performance or outreach, but the reverse is not true. Thus, we focus on financial performance in this paper. In addition, we also apply the operational self-sufficiency (OSS) ratio, a much-used sustainability benchmark in the microfinance industry. This indicator also mirrors, to a large extent, the cost/income ratio, commonly applied in traditional banking efficiency research.

\subsection{Independent variables}

In order to capture the effect of language on MFBs' financial performance in inter-firm international partnerships, we use the Ethnologue database. Ethnologue is a comprehensive, up-to-date online language database covering over 7,000 world languages. ${ }^{7}$ The database is comprised of three tables: one presents the countries with summary statistics of languages within that country; the second lists the existing languages worldwide with their genealogical classification and regional statistics. Specifically, the classification of a given language determines its place in the genealogical tree of world languages, and specifies its family, branch, sub-branch, sub-sub-branch, and so on. ${ }^{8}$ The third table presents detailed statistics on how each language is used by country, comprising over 11,000 language-country combinations (https://www.ethnologue.com/data-consulting). It must be noted that using Ethnologue allows us to draw on comprehensive and up-to-date language data. In this regard, we follow Dow and Karunaratna (2006) who drew on an earlier version of Ethnologue (Grimes, 1996).

With regard to the operationalization of Hypothesis 1, we consider whether one of the global languages - English, Spanish, or French - is a major language of the country in which the MFB is based. Following Dow and Karunaratna (2006), we consider a language a major language in a country if at least $20 \%$ of the country's population use it as their first or second language and/or it holds an official status of a statutory working language in that country. Hence, we use the notion of a major

\footnotetext{
${ }^{7}$ The description of the dataset is based on Lewis et al. (2016).

${ }^{8}$ E.g., the English language has the following classification: Indo-European $\rightarrow$ Germanic $\rightarrow$ West $\rightarrow$ English.
} 
language as a proxy for the status of an official language with regard to English, Spanish, and French. A dummy variable accounts for the presence of the global languages, English, Spanish, and French, respectively. The notion of a major language also plays a central role in our operationalization of other hypotheses.

With regard to Hypothesis 2, we account for whether a global language is shared between the MFB's country and its international partner's country. The dummy variable named "shared global language" has a value of 1 if the MFB's country and the international partner's country share at least one global language, and 0 otherwise. Similarly, three additional dummy variables specify which of the global languages, English, Spanish, or French, are shared.

With regard to Hypothesis 3, we follow Dow and Karunaratna (2006) in capturing the linguistic distance between the MFB's country and the partner's country. The linguistic distance variable denoted by $\mathrm{LD}^{f}$ is the factor loading of three-language distance indicators (L1 to L3) defined as follows:

L1: Genealogical distance between the two closest major languages (as defined in the above paragraph) spoken in the MFB's country and the partner's country, respectively. It is measured on an ordinal scale from 1 to 8 , with the following gradations: 8 - languages belong to different families; 7 - same family but different branches; 6 - same branch but different sub-branches, and so on down to gradation 1, where the languages belong to the same sub-branch at the sixth level or represent the same language. In so doing, we follow Dow and Karunaratna (2006), who used a scale from 1 to 5 in the context of a trade flow analysis. We employ a finer scale ( 1 to 8 ) because our dataset involves languages whose genealogical classification comprises significantly more than five levels. Appendices B and C list the MFBs' and international partners' countries with up to three major languages and their user bases.

L2: Incidence of MFB's country's major languages in the partner's country, measured in terms of the user base, i.e., the population of the partner's country that speaks the major language(s) of the MFB's country. In the case of several such languages, their weighted average user base is calculated (Dow \& Karunaratna, 2006), where the weights represent the population of speakers of those languages in the MFB's country (the weights are normalized to sum to unity). Following Dow and 
Karunaratna (2006), we then map the resulting linguistic user base, i.e., of the MFB's country's major languages in the partner's country, onto an ordinal scale from 1 to 5 as follows: $1=$ user base comprises $90 \%$ or more of the partner's country's population; $2=50 \%$ to $90 \% ; 3=5 \%$ to $50 \% ; 2=$ $1 \%$ to $5 \% ; 5=$ less than $1 \%$.

L3: Incidence of the partner's country's major languages in the MFB's country, measured in the same way as L2, in terms of the linguistic user base, i.e., the population of the MFB's country that speaks the major language(s) of the partner's country. In the case of several such languages, their weighted average user base is calculated, where the weights represent the population of speakers of those languages in the partner's country. The resulting linguistic user base of the partner's country's major languages in the MFB's country is then mapped onto the same ordinal scale from 1 to 5 as in the case of L2.

In addition to the above, we calculate the linguistic distance of the MFB's country to English following the same approach used to calculate L1; the resulting variable is denoted by L1MFe. In the same way, we calculate the distance of the international partner's language to English; the resulting variable is denoted by L1IPe. This procedure allows us to consider cases where English is used strategically to enhance the potential benefits of an international partnership. This is in line with previous research demonstrating that organizations can improve their relative standing and prestige by using English as a non-native lingua franca (Ku \& Zussman, 2010; Neeley \& Dumas, 2016).

\subsection{Control variables}

In order to isolate the impact of language from potentially confounding factors, we apply a number of country control variables. We account for the institutional distance between MFBs and their international partners, using aggregated values of institutional indicators from the Index of Economic Freedom developed by the Heritage Foundation (Berggren \& Jordahl, 2005; Meyer, Estrin, Bhaumik, \& Peng, 2009; Stroup, 2007). We also control for the potential effect of culture, as follows. In measuring cultural distance between MFBs and their international partners, we apply Kogut and Singh's (1988) cultural distance index, which is based on Hofstede's indices (e.g., Dow \& Karunaratna, 2006; Meyer 
et al., 2005; Filiou \& Golesorkhi, 2016). In addition, we control for geographical distance as it often relates to transportation, communication, and other transactional activities that a firm conducts when collaborating with partners (Eden \& Miller, 2004). The geographical distance between two countries is measured as the geodesic line between the countries' geographic centers, measured in kilometers (Slangen, 2011). In accounting for other exogenous factors having an influence on a country's language, we also consider colonial ties between MFBs and their international partners. Colonial ties are measured using a dummy variable. We consider the colonial empires of the UK, France, Germany, Belgium, the Netherlands, Spain, and Portugal from the period 1650 to the present (Barraclough, 1988; Dow \& Karunaratna, 2006; Srivastava \& Green, 1986). We include regional dummy variables adopted by Mersland et al. (2011) to account for the MFB's region and its international partner's region (see Table 1). Inclusion of regional dummy variables ${ }^{9}$ is helpful to control for "omitted variables" (Subramanian \& Wei, 2003). We also control for a number of MFB-specific factors that have been included in recent microfinance-performance research (Cull et al., 2007; Mersland et al., 2011), including type of ownership (non-governmental organization, cooperative, or shareholder), assets (size), MFB's age, MFB's average loan, whether the MFB is international, and whether the MFB is regulated by local banking authorities.

Insert Table 1 about here

\section{Results}

Table 2 provides descriptive statistics and the correlation matrix for the variables used in our study. None of the correlation coefficients are of high magnitude. Testing further for potential multicollinearity, we observe that the variance inflation factor reveals no symptoms of multicollinearity in the models. In Tables 3 and 4 we report the random effect specifications, using generalized least

\footnotetext{
${ }^{9}$ Given the large number of countries in our sample, we could not use country-specific fixed effect dummy variables due to methodological considerations, such as degree of freedom in regression models.
} 
squares in the panel data estimation on $405 \mathrm{MFBs}$, with missing values subject to listwise deletion, and using the inflation-adjusted ROA and OSS as the dependent variables. We choose the random effect model due to the nature of the variables of the study, which are mainly time-invariant. ${ }^{10}$ In addition, we employ random effect estimations under the assumption that the unobserved heterogeneity error term is uncorrelated with each independent variable. Testing for shared bias method as a source of endogeneity, we observe that Harman's one factor test reveals no underlying scales or structure among variables (Sharma et al., 2009).

In Tables 3 and 4, Model 1 tests the effect on an MFB's financial performance if a global language holds an official status in the MFB's country. Model 2 tests the effect on an MFB's financial performance if the MFB's country and the international partner's country share at least one global language. Model 3 tests the linguistic distance ( $\left.\mathrm{LD}^{\prime}\right)$ effect on an MFB's financial performance. Model 4 accounts for the financial performance effect of the linguistic distance of the MFB's country's major language and the partner's country's major language to English.

Insert Tables 2, 3, and 4 about here

In Model 1 (Tables 3 and 4), the MFB global language variables exhibit a positive and significant $(\mathrm{p}<0.001)$ correlation with an MFB's financial performance. This result supports Hypothesis 1 and suggests that the global language of an MFB's country enables it to capitalize on better access to knowledge and language-based resources available mainly in the high-income North. In Model 2 the variable of a shared global language also exhibits a positive and significant $(\mathrm{p}<0.001)$ correlation with an MFB's financial performance, thus supporting Hypothesis 2. Having a shared global language with an international financial partner facilitates knowledge exchange and learning that in turn enhance the MFB's financial performance. In addition, the result from Model 2 in both tables exhibits a sizable and significant $(\mathrm{p}<0.001)$ positive effect of English as a shared global language, relative to Spanish and

\footnotetext{
${ }^{10}$ This suggests that our hypothesized relationship between language and MFBs' financial performance is a stronger determinant of variation in performance across MFBs than within MFBs over time.
} 
French. The coefficient of Spanish as a shared global language is positive but only marginally significant $(\mathrm{p}<0.05)$. Although French has a positive coefficient, it is not significant. It should be noted that using three specific dummy variables (related to English, Spanish, and French) helps to reveal the stronger impact of one specific shared global language, namely English, in comparison to the other two. These results further support the argument made in Hypothesis 2 that a global language, and in particular English, shared between the MFB's country and its international financial partner's country contributes positively to the MFB's financial performance.

In Models 3 and 4 (Tables 3 and 4), the $\mathrm{LD}^{f}, \mathrm{~L} 1 \mathrm{MFe}$, and L1IPe variables are negative and significant $(\mathrm{p}<0.01)$. It must be noted that we control for a shared global language in both Models 3 and 4 , so as not to overestimate the importance of linguistic distance. Our results support the prediction of Hypothesis 3 that the linguistic distance between an MFB and its international financial partner has a negative effect on the MFB's financial performance. These results indicate that the use of the English language stimulates exchange of capabilities, knowledge, and other resources, thus improving the performance of the MFB. Due to its international scope, English linguistically dominates the microfinance industry and thus, e.g., the English language proficiency of an MFB's staff members is important for its performance. ${ }^{11}$

Tables 3 and 4 also reveal that a number of control variables are significantly associated with the performance of the MFB. The institutional distance variable is significant $(\mathrm{p}<0.01)$ and have a negative impact on an MFB's performance in all models. The significance of this variable highlights the disparity of the institutional settings (e.g., legal, political, and regulatory) in which MFBs and their international financial partners operate. The colonial variable is also significant $(\mathrm{p}<0.05)$ in all models in both tables, highlighting the diverse language environment in the MFB's country due to its colonial past. We observe that the MFB's age is positive and significant $(\mathrm{p}<0.01)$ in all models, which could be expected

\footnotetext{
${ }^{11}$ Our results remain robust if the linear measurement scale of L1 variables is replaced with a non-linear, convex decreasing scale. Specifically, the L1 construct is then measured in such a way that the difference between languages on the family level is perceived to be stronger than the difference on the branch level; correspondingly, the difference on the branch level is perceived to be stronger than the difference on the subbranch level, and so on. We considered several different variations of this approach. The details are available on request.
} 
as the MFB achieves positive learning effects over time. Regulation of an MFB by banking authorities exhibits a negative impact in all models and is significant in Models 2 and $3(\mathrm{p}<0.05$ and $\mathrm{p}<0.01$, respectively), illustrating the high costs involved in being regulated. The MFB's size has a positive and significant effect $(\mathrm{p}<0.01$ in all models) on its financial performance, which indicates the existence of organization-level scale economies in microfinance banking.

\section{Discussion}

The purpose of this paper was to explore the effect of language use on the organization-level performance of microfinance banks that engage in international inter-firm partnerships. In international business research, language has often been considered a "soft" issue that shapes the quality of interaction between the communicating parties. To date, there has been very little empirical evidence of the "hard" monetary effect of language use. Furthermore, previous research has looked at initial international expansion in terms of recognition of international opportunities (Hurmerinta et al., 2015), exporting (Crick, 1999; Leonidou, 1995), and foreign-market entry modes (Lopez-Duart \& VidalSuárez, 2010) rather than at the more long-term effects of language on firm survival and performance.

Based on panel data of 405 rated MFBs located in 74 low-income countries, we made four contributions to language research in international business. First, we provided robust empirical evidence of the relationship between language use and performance of MFBs. All our hypotheses were supported, indicating that language has an important effect on MFBs' performance. Specifically, in Hypothesis 1 we found that a global language that holds a major status in the MFB's country provides better access to and utilization of key resources (e.g., knowledge and capital) from high-income developed countries. This performance-enhancing effect can be explained by the fact that the bulk of microfinance knowledge, in the form of guidelines and support, is available primarily in one of the global languages.

As for Hypothesis 2, we found that the presence of a shared global language between the MFB's country and the international partner's country results in better performance of the MFB. We argued that a shared global language facilitates a common understanding of how the partners in question solve 
problems, de-codify knowledge flows, manage the partnership, and establish which rules of engagement to follow.

Furthermore, when testing Hypothesis 3, we found that MFBs' performance is negatively affected by the linguistic distance between its home country and its international partner's country. These effects can be due to both ex ante factors before forming the partnership, e.g., unfavorable conditions for making a good contract with the partner, as well as ex post factors, e.g., higher costs of monitoring and communication. Although we measured linguistic distance as an exogenous variable to MFBs' performance, we also noted that MFBs' organization-specific policies of language training and recruitment may reduce this negative effect. This further suggests that MFBs with English-proficient staff members can be expected to have better access to complementary resources, competencies, technologies, and skills from their international partners. The case study of Oxfam by Lehtovaara (2009) produced similar results.

Secondly, in studying dyadic relationships between the MFB and its international financial partners we complemented and extended previous research by shifting the attention from intra-firm partnerships, particularly headquarters-subsidiary ones, to inter-firm partnerships (Boussebaa et al., 2014; Cuypers et al., 2015). Contractual agreements of this kind differ from equity-based relationships between MNC headquarters and wholly owned subsidiaries in terms of the degree of control and influence that the parties can exercise over each other. For example, international financial partners cannot impose a common corporate language on the MFB in the same way that MNC headquarters can on its foreign subsidiary. In practice, the default language choice is highly pragmatic, and it is often the only idiom that the partners from the South and the North share with each other. Research on international alliances is only beginning to consider language differences between partners (Brannen \& Salk, 2000; Liu et al., 2015; Joshi \& Lahiri, 2015). Although past international business research has explored the impact of institutional differences on the performance of international alliances (e.g., Filiou \& Golesorkhi, 2016; Lavie \& Miller, 2008), we took this issue down to a more disaggregated level by addressing the specific effect of language on organization-based performance.

Thirdly, our findings highlighted the importance of language for service provision. Previous research on language in international business has largely focused on the manufacturing sector rather than the 
service sector (for exceptions, see Piekkari, Welch, Welch, Peltonen, \& Vesa, 2013; Sanden, 2015). The microfinance industry represents global services that are highly language-dependent (Holmqvist, 2009; Sanden, 2015). In this paper, we argued that local customers' experiences of service quality (including the cost of loans) are ultimately a function of the quality of interaction between the MFB and its international partners. Our findings showed that this interaction is shaped by language use and significantly affects the performance of the MFB. Compared to products, services are more sensitive to language due to the direct interaction between the MFB as the service provider and local borrowers as the customers. The delivery of financial services requires high involvement from the firm in terms of providing relevant information, taking risks, and actively participating in the service process (Holmqvist, 2009; Holmqvist \& Van Vaerenbergh, 2013). Holmqvist and Grönroos (2012) point out that language considerations do not only influence the service encounter, but also the customers' initial choice of the service provider, their intention to repurchase the service, and overall satisfaction with the service. While we did not study whether MFBs experience language-related challenges in their interaction with local customers, we identified such challenges in the relationships with international partners.

Fourthly, our study focused on MFBs in emerging markets. We argued that from the viewpoint of low-income countries, language skills are typically more important for economic activity and international trade than for organizations based in more mature economies, partly because of the relative scarcity of such skills in emerging economies. Previous research has been dominated by studies on MNCs in developed markets such as the Nordic countries (Andersen \& Rasmussen, 2004; MarschanPiekkari et al., 1999a, 1999b) and Japan (Neeley \& Dumas, 2016). Our sample of MFBs and their international financial partners covered a broader range of language environments, with a high number of MFBs based in Asia, Africa, and Latin America.

\section{Conclusion}

This study was partly motivated by the authors' first-hand experience of working with microfinance organizations and being exposed to significant language-related effects that generated operational costs. For example, we observed how language-proficient staff members had to accompany auditors or 
directors on their site visits and leave their own tasks aside, and how large international business meetings could not be organized because participants first had to be divided into several smaller language-based groups to ensure meaningful communication. We have witnessed CEOs who were recruited based primarily on their superior language capabilities rather than management capabilities, or key executives who first had to be sent for language training for 6-12 months before they could start working. During our more than 25 years of practical experience in the microfinance industry, we have repeatedly observed the costs accrued due to language barriers between MFBs and their international financial partners. And the findings of our global survey confirm this: language differences, if not effectively managed, hamper the outcome of international partnerships.

International partnerships between organizations based in developed and emerging markets are on the rise (The Economist, 2015). Specifically, our results provide managerial guidance to MFBs seeking international financial partners as well as to international microfinance stakeholders searching for MFB partners. When potential international financial partners are considered in the microfinance industry, their ability to speak English as a lingua franca should be a major consideration. We argue that relatively small investments in language training would offer considerable return on investment, because training can be targeted to a relatively limited number of key individuals. The strong advantage of Englishspeaking partners reflects the language intensity and communication challenges of the microfinance industry more generally. However, MFBs and language-intensive partnerships in other industries can take countermeasures by strengthening their communication abilities in English or other common languages accessible to the partners.

One of the limitations of this study is that we used country-based factors (linguistic distance and shared global language) to measure organization-level outcomes (the MFB's financial performance). Organizations within one country will vary in their ability to deal with language differences on a global scale (for example, an organization based in Florida has the advantage of using Spanish over an organization based in Idaho). Moreover, organizations can take remedies such as recruitment and training to substantially reduce their home-based linguistic disadvantage. However, we would like to point out that our observations are based on panel data that indicate a significant and persistent negative effect of linguistic distance on the financial performance of MFBs over time. This finding points to the 
inability, in full or in part, of microfinance partnerships to alleviate language-based costs. We believe this is a common challenge in many inter-firm relationships between partners from developed and emerging countries. In other sectors that are more competitive and in developed countries, we expect such suboptimal relationships to be less persistent. However, managers should still be aware of this potential pitfall, as significant costs could incur before the root cause of faulty inter-firm communications is discovered.

Another limitation of our study is that we focused only on one particular industry. MFBs and their international partnerships are not traditional business partnerships and one needs to be aware that the choice of partners depends on a range of factors other than language alone. These include availability and opportunities of partnerships as well as the MFB's own resource endowments and capabilities (e.g., Hoffmann, 2007). Such factors could represent confounding firm-level effects on partners' proficiency in English, but these lie beyond the scope of this study. Thus, follow-up studies are needed in other industries. Nevertheless, we would argue that the diversity of MFBs and countries included in our sample provides a basis for some generalization.

Although the results of this study primarily consider the effect of English as the dominant language in international business, a significant amount of microfinance-specific knowledge has been developed in Latin America, particularly in Bolivia and Peru. This makes it interesting for future research to investigate the particular role of the Spanish language in this sector. Furthermore, we see a need to address how both new and experienced organizations can become better at mitigating language and other communication-derived costs in international partnerships. Finally, we invite the languagesensitive community in international business to move beyond business settings, e.g., to the domain of international development and aid. This is an area closely related to the microfinance industry, with abundant international activities and presumably significant language-related costs.

\section{Acknowledgments}

We are grateful to Hilla Polvinen for her research assistance and to Sarianna Lundan for her valuable comments on an earlier draft of this paper. 


\section{REFERENCES}

Access-Assist (2014). Report on human resource management in microfinance institutions: The state of practice. New Delhi: Access-Assist.

Andersen, H., \& Rasmussen, E. S. (2004). The role of language skills in corporate communication. Corporate Communication: An International Journal, 9(2), 231-242.

Armendáriz, B., \& Morduch, J. (2010). The Economics of Microfinance (2nd ed.). Cambridge, MA: MIT Press.

Banerjee, A., Karlan, D., \& Zinman, J. (2015). Six randomized evaluations of microcredit: Introduction and further steps. American Economic Journal: Applied Economics, 7(1), 1-21.

Barner-Rasmussen, W. (2003). Knowledge sharing in multinational corporations: A social capital perspective. Helsinki: Swedish School of Economics and Business Administration $[\mathrm{PhD}$ dissertation].

Barner-Rasmussen, W., Ehrnrooth, M., Koveshnikov, A., \& Mäkelä, K. (2014). Cultural and language skills as resources for boundary spanning within the MNC. Journal of International Business Studies, 45(7), 886-905.

Barraclough, D. R. (1988). International geometric reference field revision 1987. Geophysics, 53(4), $576-578$.

Beisland, L. A., \& Mersland, R. (2012). Do microfinance rating assessments make sense? An analysis of the drivers of MFB ratings. Nonprofit and Voluntary Sector Quarterly, 41(2), 213-231.

Beisland, L. A., Mersland, R., \& Randøy, T. (2014). Transparency and disclosure in the global microfinance industry: Implications for practice and policy makers. In J. Forssbaeck, \& L. Oxelheim (Eds.). The Oxford Handbook of Political, Institutional, and Corporate Transparency. New York: Oxford University Press, pp. 434-455.

Berggren, N., \& Jordahl, H. (2005). Does free trade really reduce growth? Further testing using the economic freedom index. Public Choice, 122(1), 99-114.

Björkman, A., \& Piekkari, R. (2009). Language and foreign subsidiary control: An empirical test. Journal of International Management, 15(1), 105-117. 
Boussebaa, M., Sinha, S., \& Gabriel, Y. (2014). Englishization in offshore call centers: A postcolonial perspective. Journal of International Business Studies, 45(9), 1152-1169.

Brannen, M. Y., \& Salk, J. E. (2000). Partnering across borders: Negotiating organizational culture in a German-Japanese joint venture. Human Relations, 53(4), 451-487.

Brannen, M. Y., \& Doz, Y. L. (2012). Corporate languages and strategic agility? Trapped in your jargon or lost in translation? California Management Review, 54(3), 77-97.

Brannen, M. Y., Piekkari, R., \& Tietze, S. (2014). The multifaceted role of language in international business: Unpacking the forms, functions and features of a critical challenge to MNC theory and performance. Journal of International Business Studies, 45(5), 495-507.

Brannen, M. Y., \& Mughan, T. (Eds.) (2017). Language in International Business: Developing a Field. Basingstoke: Palgrave Macmillan.

Bruton, G. D., Kahvul, S., \& Chavez, H. (2011). Microlending in emerging economies: Building a new line of inquiry from the ground up. Journal of International Business Studies, 42(5), 718-739.

CILT - National Centre for Languages (2006). ELAN: Effects on the European economy of shortages of foreign language skills in enterprise. European Commission.

Crick, D. (1999). An investigation into SME's use of languages in their export operations. International Journal of Entrepreneurial Behaviour and Research, 5(1), 19-31.

Crystal, D. (2003). English as a Global Language (2nd ed.). Cambridge, NY: Cambridge University Press.

Cull, R., Demirgûç-Kunt, A., \& Morduch, J. (2007). Financial performance and outreach: A global analysis of leading microbanks. Economic Journal, 117(517), F107-F133.

Cuypers, I. R. P., Ertug, G., \& Hennart, J. F. (2015). The effects of linguistic distance and lingua franca proficiency on the stake taken by acquirers in cross-border acquisitions. Journal of International Business Studies, 46(4), 429-442.

Dow, D., Cuypers, I. R. P., Ertug, G. (2016). The effects of within-country linguistic and religious diversity on foreign acquisitions. Journal of International Business Studies, 47(3), 319-346.

Dow, D., \& Karunaratna, A. (2006). Developing a multidimensional instrument to measure psychic distance stimuli. Journal of International Business Studies, 37(5), 578-602. 
Drori, I., Manos, R., Santacreu-Vasut, E., Shenkar, O., \& Shoham, A. (2018). Language and market inclusivity for women entrepreneurship, the case of microfinance. Journal of Business Venturing, $33(4), 395-415$.

Eden, L., \& Miller, S. R. (2004). Distance matters: Liability of foreignness, institutional distance and ownership strategy. In M. Hitt, \& J. Cheng (Vol. Eds.). Advances in International Management, Vol. 16. Amsterdam: Elsevier, pp. 187-221.

Fan, S. X., Cregan, C., Harzing, A.-W., \& Kohler, T. (2018). The benefits of being understood: The role of ethnic identity confirmation in knowledge acquisition by expatriates. Human Resource Management, 57(1), 327-340.

Filiou, D., \& Golesorkhi, S. (2016). Influence of institutional differences on firm innovation from international alliances. Long Range Planning, 49(1), 129-144.

Foreman-Peck, J., \& Wang, Y. (2014). The costs to the UK of language deficiencies as a barrier to UK engagement in exporting. A report to UK trade \& investment. Cardiff, UK: Cardiff Business School.

Fredriksson, R., Barner-Rasmussen, W., \& Piekkari, R. (2006). The multinational corporation as a multilingual organization: The notion of a shared corporate language. Corporate Communications: An International Journal, 11(4), 406-423.

Freeman, M., \& Olson-Buchanan, J. (2013). The relations between expatriate personality and language fluency and its effect on host country adjustment: An empirical study. International Journal of Management, 30(2), 393-401.

Galema, R., Lensink, R., \& Mersland, R. (2012). Do powerful CEOs have an impact on microfinance performance? Journal of Management Studies, 49(4), 718-742.

Guérin, I., \& Kumar, S. (2017). Market, freedom and the illusions of microcredit. Patronage, caste, class and patriarchy in the rural south India. Journal of Development Studies, 53(5), 741-754.

Grimes, B. F. (1996). Ethnologue: Languages of the World. Dallas, TX: International Academic Bookstore.

Hagen, S. (1999). Business communication across borders. A study of language use and practice in European countries. London: Languages National Training Organisation.

Hall, E. T. (1959). The Silent Language. Garden City, NY: Doubleday \& Co. 
Hartarska, V. (2005). Governance and performance of microfinance institutions in central and eastern Europe and the newly independent states. World Development, 33(10), 1627-1648.

Harzing, A.-W., \& Pudelko, M. (2013). Language competencies, policies and practices in multinational corporations a comprehensive review and comparison of Anglophone, Asian, Continental European and Nordic MNCs. Journal of World Business, 48(1), 87-97.

Harzing, A.-W., \& Pudelko, M. (2014). Hablas vielleicht un peu la mia language? A comprehensive overview of the role of language differences in headquarters-subsidiary communication. International Journal of Human Resource Management, 25(5), 696-717.

Heimeriks, K. H., \& Duysters, G. (2007). Alliance capability as a mediator between experience and alliance performance: An empirical investigation into the alliance capability development process. Journal of Management Studies, 44(1), 25-49.

Heimeriks, K. H., Klijn, E., \& Reuer, J. J. (2009). Building capabilities for alliance portfolios. Long Range Planning, 42(1), 96-114.

Hoffmann, W. H. (2007). Strategies for managing a portfolio of alliances. Strategic Management Journal, 28(8), 827-856.

Holden, N. (1998). International marketing studies: Time to break the English strangle-hold? International Marketing Review, 15(2), 86-100.

Holmqvist, J. (2009). Language influence in services: Perceived importance of native language use in service encounters. Publication No. 194, Helsinki: Hanken School of Economics [PhD dissertation].

Holmqvist, J., \& Grönroos, C. (2012). How does language matter for services? Challenges and propositions for service research. Journal of Service Research, 15(4), 430-442.

Holmqvist, J., \& Van Vaerenbergh, Y. (2013). Perceived importance of native language use in service encounters. The Service Industries Journal, 33(15-16), 1659-1671.

Holmqvist, J., Van Vaerenbergh, Y., \& Grönroos, C. (2017). Language use in services: Recent advances and directions for future research. Journal of Business Research, 72(1), 114-118.

Hudon, M., \& Sandberg, J. (2013). The ethical crisis in microfinance: Issues and findings. Business Ethics Quarterly, 23(4), 561-589. 
Hummels, H., \& Millone, M. (2014). The social function of asset classes in microfinance: Enhancing performance through donations, private equity and debt. In R. Mersland, \& R. Ø. Strøm (Eds.) Microfinance Institutions: Financial and Social Performance. Houndmills, UK: Palgrave Macmillan.

Hurmerinta, L., Nummela, N., \& Paavilainen-Mäntymäki, E. (2015). Opening and closing doors: The role of language in international opportunity recognition and exploitation. International Business Review, 24(6), 1082-1094.

Håkanson, L., Ambos, B., Schuster, A., \& Leicht-Deobald, U. (2016). The psychology of psychic distance: Antecedents of asymmetric perceptions. Journal of World Business, 51(2), 308-318.

Ishii, K. (2012). Dual organizational identification among Japanese expatriates: The role of communication in cultivating subsidiary identification and outcomes. The International Journal of Human Resource Management, 23(6), 1113-1128.

Jeanjean, T., Stolowy, H., Erkens. M., \& Yohn, T. L. (2015). International evidence on the impact of adopting English as an external reporting language. Journal of International Business Studies, 46(2), $180-205$.

Johanson, J., \& Wiedersheim-Paul, F. (1975). The internationalization of the firm: Four Swedish cases. Journal of Management Studies, 12(3), 305-322.

Joshi, A. M., \& Lahiri, N. (2015). Language friction and partner selection in cross-border R\&D alliance formation. Journal of International Business Studies, 46(2), 123-152.

Karhunen, P., Kankaanranta, A., Louhiala-Salminen, L., \& Piekkari, R. (2018). Let's talk about language: A review of language-sensitive research in international management. Journal of Management Studies, 55(6), 980-1013.

Kedia, B. L., \& Reddy, R. K. (2016). Language and cross-border acquisitions: An exploratory study. International Business Review, 25(6), 1321-1332.

Kogut, B. \& Singh, H. (1988). The effect of national culture on the choice of entry mode. Journal of International Business Studies, 19(3), 411-432.

Ku, H., \& Zussman, A. (2010). Lingua franca: The role of English in international trade. Journal of Economic Behavior \& Organization, 75(2), 250-260. 
Lauring, J., \& Selmer, J. (2013). Linguistic diversity and English language use in multicultural organizations: Is there a moderating effect of the age of organizational members? The International Journal of Human Resource Management, 24(10), 1985-1996.

Lavie, D., \& Miller, S. R. (2008). Collaboration portfolio internationalization and firm performance. Organization Science, 19(4), 623-646.

Lehtovaara, H. (2009). Working in four official languages: The perceptions of OGB employees on the role of language in internal communication. Helsinki: Helsinki School of Economics [Master's thesis].

Leonidou, L. C. (1995). Empirical research on export barriers: Review, assessment, and synthesis. Journal of International Marketing, 3(1), 29-43.

Lewis, M., Simons, G., \& Fennig, C. (2016). Ethnologue: Languages of the World (nineteenth edition). Dallas, TX: SIL International. Online: http://www.ethnologue.com.

Liu, A. L., Adair, W. L., \& Bello, D. C. (2015). Fit, misfit, and beyond fit: Relational metaphors and semantic fit in international joint ventures. Journal of International Business Studies, 46(7), 830849.

Lloyd's (2012). Insurance in developing countries: Exploring opportunities in microinsurance. Lloyd's $360^{\circ}$ Risk Insight and MicroInsurance Centre. London: Lloyd's Insurance.

Lopez-Duarte, C., \& Vidal-Suárez, M. M. (2010). External uncertainty and entry mode choice: Cultural distance, political risk and language diversity. International Business Review, 19(6), 575-588.

Luo, Y., \& Shenkar, O. (2006). The multinational corporation as a multilingual community: Language and organization in a global context. Journal of International Business Studies, 37(3), 321-339.

MacDonald, S., \& Cook, M. (1998). An exploration of the use of language training in exporting firms. Case studies from Northamptonshire. Local Economy, 13(3), 216-227.

Marschan, R., Welch, D., \& Welch, L. (1997). Language: The forgotten factor in multinational management. European Management Journal, 15(5), 591-598.

Marschan-Piekkari, R., Welch, D. E., \& Welch, L. S. (1999a). In the shadow: The impact of language on structure, power and communication in the multinational. International Business Review, 8(4), $421-440$. 
Marschan-Piekkari, R., Welch, D. E., \& Welch, L. S. (1999b). Adopting a shared corporate language: IHRM implications. International Journal of Human Resource Management, 10(3), 377-390.

Mersland, R. (2009). The cost of ownership in micro-finance organizations. World Development, 37(2), $469-478$.

Mersland, R., Randøy, T., \& Strøm, R. Ø. (2011). The impact of international influence on microbanks' performance: A global survey. International Business Review, 20(2), 163-176.

Mersland, R., \& Strøm, R. Ø. (2009). Performance and governance in microfinance institutions. Journal of Banking and Finance, 33(4), 662-669.

Mersland, R., \& Strøm, R. Ø. (2010). Microfinance mission drift? World Development, 38(1), 28-36.

Mersland, R., \& Strøm, R. Ø. (2012). The past and future of innovations in microfinance. In D. Cumming (Ed.). The Oxford Handbook of Entrepreneurial Finance. Oxford, NY: Oxford University Press, pp. 859-892.

Meyer, K. E., Estrin, S., Bhaumik, S. K., \& Peng, M. W. (2009). Institutions, resources, and entry strategies in emerging economies. Strategic Management Journal, 30(1), 61-80.

Monteiro, L. F., Arvidsson, N., \& Birkinshaw, J. (2008). Knowledge flows within multinational corporations: Explaining subsidiary isolation and its performance implications. Organization Science, 19(1), 90-107.

Morduch, J. (1999). The microfinance promise. Journal of Economic Literature, 37(4), 1569-1614.

Mughan, T. (1990). Is "languages for export” enough? European Business Review, 90(3), 22-25.

Mäkelä, K., Kalla, H., \& Piekkari, R. (2007). Interpersonal similarity as a driver of knowledge sharing within multinational corporations. International Business Review, 16(1), 1-22.

Neeley, T. B., \& Dumas, T. L. (2016). Unearned status gain: Evidence from a global language mandate. Academy of Management Journal, 59(1), 14-43.

Peltokorpi, V. (2015). Corporate language proficiency and reverse knowledge transfer in multinational corporations: Interactive effects of communication media richness and commitment to headquarters. Journal of International Management, 21(1), 49-62. 
Peltokorpi, V., \& Vaara, E. (2014). Knowledge transfer in multinational corporations: Productive and counterproductive effects of language-sensitive recruitment. Journal of International Business Studies, 45(5), 600-622.

Piekkari, R., Welch, D. E., \& Welch, L. S. (2014). Language in International Business: The Multilingual Reality of Global Business Expansion. Cheltenham, UK: Edward Elgar.

Piekkari, R., Welch, D., Welch, L., Peltonen J.-P., \& Vesa, T. (2013). Translation behaviour: An exploratory study within a service multinational. International Business Review, 22(5), 771-783.

Piekkari, R., \& Westney, E. (2017). Language as a meeting ground for research on the MNC and organization theory. In C. Dörrenbächer \& M. Geppert (Eds.). Multinational Corporations and Organization Theory: Post Millennium Perspectives (Series: Research in the Sociology of Organizations). Bingley, UK: Emerald Publishing Limited, pp. 193-232.

Randøy, T., Strøm, R. Ø., \& Mersland, R. (2015). The impact of entrepreneur-CEOs in microfinance institutions: A global survey. Entrepreneurship Theory and Practice, 39(4), 927-953.

Reed, L. (2013). Vulnerability: The State of the Microcredit Summit Campaign Report. Washington, D.C.: Microcredit Summit Campaign.

Reiche, B. S., Harzing, A.-W., \& Pudelko, M. (2015). Why and how does shared language affect subsidiary knowledge inflows? A social identity perspective. Journal of International Business Studies, 46(5), 528-551.

Sanden, G. R. (2015). Corporate language policies: What are they? Journal of Economics, Business and Management, 3(11), 1097-1101.

Schomaker, M. S., \& Zaheer, S. (2014). The role of language in knowledge transfer to geographically dispersed manufacturing operations. Journal of International Management, 20(1), 55-72.

Selmer, J. (2006). Language ability and adjustment: Western expatriates in China. Thunderbird International Business Review, 48(3), 347-368.

Sharma, R., Yetton, P., \& Crawford, J. (2009). Estimating the effect of common method variance: The method-method pair technique with an illustration from TAM research. MIS Quarterly, 33(3), 473490. 
Simons, G. F., \& Fennig, C. D. (Eds.). (2018). Ethnologue: Languages of the World (21st ed.). Dallas, Texas: SIL International. Online version: http://www.ethnologue.com.

Slangen, A. (2011). A communication-based theory of the choice between greenfield and acquisition theory. Journal of Management Studies, 48(8), 1699-1726.

Srivastava, R. K., \& Green, R. T. (1986). Determinants of bilateral trade flows. Journal of Business, 59(4), 623-640.

Stroup, M. D. (2007). Economic freedom, democracy, and the quality of life. World Development, $35(1), 52-66$.

Subramanian, A., \& Wei, S. (2003). The WTO promotes trade, strongly but unevenly. IMF Working Paper.

Swift, J. S. (1991). Foreign language ability and international marketing. European Journal of Marketing, 25(12), 36-49.

Swift, J. S. (1993). Problems with learning foreign languages for international business. Journal of European Industrial Training, 17(10), 35-42.

Swift, J. S., \& Wallace, J. (2011). Using English as the common corporate language in a German multinational. Journal of European Industrial Training, 35(9), 892-913.

Tenzer, H., Terjesen, S., \& Harzing, A.-W. (2017). Language in international business research: A review and agenda for future research. Management International Review, 57(8), 815-854.

Tietze, S., Tansley, C., \& Helienek, E. (2017). The translator as agent in management knowledge transfer. International Journal of Cross-Cultural Management, 17(1), 151-169.

The Economist (2015). http://www.economist.com/blogs/democracyinamerica/2014/04/foreign-aid (accessed May 13, 2016).

Wang, Y-L. (2012). Effects of cross-cultural and language training on expatriates' adjustment and job performance in Vietnam. Asia Pacific: Journal of Human Resources, 50(3), 327-350.

Yin, R. K. (2014). Case Study Research: Design and Methods. Thousand Oaks: Sage publications.

Zollo, M., Reuer, J. J., \& Singh, H. (2002). Interorganizational routines and performance in strategic alliances. Organization Science, 13(6), 701-713. 


\section{Table 1}

\section{Definition of Variables}

\section{Variables \\ Dependent variables}

Return on assets (ROA)

Operational self-sufficiency (OSS)

\section{Independent variables}

MFB global language

Shared global language

Shared global lang. English

Shared global lang. French

Shared global lang. Spanish

Linguistic distance $\left(\mathrm{LD}^{f}\right)$

L1: Genealogical distance between the two closest major languages spoken in the MFB's country and the partner's country

L2: Incidence of MFB's country's major languages in the partner's country

L3: Incidence of the partner's country's major languages in the MFB's country

Linguistic distance of the MFB's country to English (L1MFe)

Linguistic distance of the international partner's country to English (L1IPe)

\section{Country control variables}

Institutional difference based on indicators including business, trade, fiscal, investment, financial, monetary, labor freedom, freedom from corruption, property rights, and government size

Operational net income divided by average annual assets and adjusted for country inflation

Interest and commissions earned on the loan portfolio divided by the sum of operational costs, default cost, and funding costs

Indicates whether one of the global languages, i.e., English, French, or Spanish, is the major language of the country in which the MFB is based

English $\mathrm{Yes}=1, \mathrm{No}=0$

French $\mathrm{Yes}=1, \mathrm{No}=0$

Spanish $\mathrm{Yes}=1, \mathrm{No}=0$

Indicates whether one or more of the following is true: the MFB and their partners have a shared global language, either English, French, or Spanish $\mathrm{Yes}=1, \mathrm{No}=0$

Indicates whether English is the shared global language between MFBs and their partners $\mathrm{Yes}=1, \mathrm{No}=0$

Indicates whether French is the shared global language between MFBs and their partners

$\mathrm{Yes}=1, \mathrm{No}=0$

Indicates whether Spanish is the shared global language between MFBs and their partners

$\mathrm{Yes}=1, \mathrm{No}=0$

Factor loading

0.958

The same approach to calculating L1 is used

The same approach to calculating L1 is used

For each of these 10 indicators we compute the aggregate institutional difference using the formula $\sum_{j=1}^{10}\left|\mathrm{IM}_{j}-\mathrm{IP}_{J}\right|$, where $\mathrm{IM}_{j}$ represents the value of the $j$ th indicator for the MFB's country, and $\mathrm{IP}_{j}$ - for the partner's country, respectively. 
Cultural distance based on Hofstede original cultural dimensions of power distance, uncertainty avoidance, individuality, and masculinity/femininity

Colony

Geographical distance

Region Africa

Region Asia

Region EECA

Region Latin America

Region MENA

Region Europe

Region North America

\section{MFB control variables}

International MFB

MFB age

Type

Regulation

Assets

Average loan
We use Kogut and Singh's (1988) index $\frac{1}{4} \sum_{j=1}^{4}\left(\mathrm{CM}_{j}-\mathrm{CP}_{J}\right)^{2} / V_{J}$, where $\mathrm{CM}_{j}$ represents the value of the $j$ th indicator for the MFB's country, and $\mathrm{CP}_{j}-$ for the partner's country, respectively. Further, $V_{j}$ represents the variance of indicator $j$.

Indicates that one or more of the following is true: MFBs share a colonial link with international partners of empires of the UK, France, Germany, Belgium, the Netherlands, Spain, or Portugal post-1650.

$\mathrm{Yes}=1, \mathrm{No}=0$

Distance between two countries is measured along the geodesic joining the countries' geographic centers, in kilometers

Indicates whether MFBs' countries are in Sub-Saharan Africa $\mathrm{Yes}=1, \mathrm{No}=0$

Indicates whether MFBs' countries are in the Asia-Pacific region

$\mathrm{Yes}=1, \mathrm{No}=0$

Indicates whether MFBs' countries are in Eastern Europe and Central Asia

$\mathrm{Yes}=1, \mathrm{No}=0$

Indicates whether MFBs' countries are in Latin America and the Caribbean

$\mathrm{Yes}=1, \mathrm{No}=0$

Indicates whether MFBs' countries are in the Middle East and North Africa

$\mathrm{Yes}=1, \mathrm{No}=0$

Indicates whether international partners' countries are in Europe

$\mathrm{Yes}=1, \mathrm{No}=0$

Indicates whether international partners' countries are in North America

$\mathrm{Yes}=1, \mathrm{No}=0$

Indicates whether one or more of the following is true: the MFB is a member of an international network; the MFB has an international initiator/director; the MFB has international debt

$\mathrm{Yes}=1, \mathrm{No}=0$

The natural logarithm of the years (lagged by one year) since the MFB started microfinance operations

Indicates whether the MFB is a shareholder firm or a nonprofit firm (we have grouped NGOs and cooperatives under nonprofit firms and non-bank financial institutions and banks under shareholder firms)

Shareholder $=1$, nonprofit $=0$

Indicates whether the MFB is regulated by banking authorities $\mathrm{Yes}=1, \mathrm{No}=0$

The natural logarithm of the MFB's assets

Average outstanding loan per loan client 


\section{Table 2}

\section{Bivariate Correlation Matrix}

\begin{tabular}{|c|c|c|c|c|c|c|c|c|c|c|c|c|c|c|c|c|c|c|c|c|c|c|}
\hline & Mean & Std. & 1 & 2 & 3 & 4 & 5 & 6 & 7 & 8 & 9 & 10 & 11 & 12 & 13 & 14 & 15 & 16 & 17 & 18 & 19 & 20 \\
\hline 1. ROA & 0.113 & 0.104 & 1 & & & & & & & & & & & & & & & & & & & \\
\hline 2. OSS & 1.211 & 0.811 & $0.67^{*}$ & 1 & & & & & & & & & & & & & & & & & & \\
\hline 3. MFB global lang. English & 0.113 & 0.104 & 0.04 & 0.02 & 1 & & & & & & & & & & & & & & & & & \\
\hline 4. MFB global lang. French & 0.367 & 0.218 & 0.05 & 0.06 & $-0.07 *$ & 1 & & & & & & & & & & & & & & & & \\
\hline 5. MFB global lang. Spanish & 0.142 & 0.034 & 0.01 & 0.03 & -0.11 & $-0.12 *$ & 1 & & & & & & & & & & & & & & & \\
\hline 6. Shared global language & 0.325 & 0.467 & 0.10 & 0.11 & $0.13 *$ & 0.14 & $0.12 *$ & 1 & & & & & & & & & & & & & & \\
\hline 7. Shared global lang. English & 0.182 & 0.387 & 0.22 & 0.14 & $0.15^{*}$ & -0.18 & -0.17 & $0.19 *$ & 1 & & & & & & & & & & & & & \\
\hline 8. Shared global lang. French & 0.101 & 0.302 & 0.16 & 0.14 & $-0.08^{*}$ & $0.10 *$ & 0.21 & $0.18^{*}$ & -0.15 & 1 & & & & & & & & & & & & \\
\hline 9. Shared global lang. Spanish & 0.042 & 0.120 & 0.11 & 0.15 & -0.07 & $0.17^{*}$ & $0.22 *$ & $0.19^{*}$ & -0.23 & 0.25 & 1 & & & & & & & & & & & \\
\hline 10. $\mathrm{LD}^{f}$ & 0.000 & 1.000 & -0.01 & -0.02 & -0.03 & -0.04 & $-0.03 *$ & -0.04 & $-0.06 *$ & -0.01 & -0.01 & 1 & & & & & & & & & & \\
\hline 11. Institutional distance & 14.365 & 11.017 & -0.03 & $-0.14 * *$ & $-0.25 *$ & $-0.20^{*}$ & -0.01 & -0.01 & $-0.23 * *$ & -0.19 & -0.17 & $0.24 *$ & 1 & & & & & & & & & \\
\hline 12. Cultural distance & 0.481 & 1.013 & -0.08 & -0.01 & $0.10^{*}$ & 0.05 & $0.08 * *$ & -0.09 & -0.11 & -0.12 & -0.16 & $0.22 *$ & $0.25^{*}$ & 1 & & & & & & & & \\
\hline 13. Colony & 0.142 & 0.352 & 0.31 & 0.25 & 0.12 & 0.18 & 0.19 & $0.20^{*}$ & $0.16^{*}$ & $0.13^{*}$ & $0.23 *$ & $0.21 *$ & 0.24 & $0.12^{*}$ & 1 & & & & & & & \\
\hline 14. Geographical distance & 8,351 & 3644 & -0.22 & -0.18 & $-0.11 *$ & $-0.23^{*}$ & -0.15 & $-0.18^{*}$ & -0.11 & -0.18 & -0.10 & $0.15^{*}$ & $0.16^{* *}$ & $0.11^{*}$ & $-0.12 * *$ & 1 & & & & & & \\
\hline 15. International MFB & 0.737 & 0.440 & $-0.06^{*}$ & $-0.19 *$ & $0.22 * *$ & $0.21 *$ & 0.06 & 0.02 & $0.04 *$ & 0.01 & $0.07 *$ & $-0.19 * *$ & $-0.08^{*}$ & $-0.09 *$ & $-0.14 *$ & $-0.18 *$ & 1 & & & & & \\
\hline 16. Regulation & 0.283 & 0.448 & -0.11 & -0.03 & 0.05 & $-0.08 * *$ & ${ }^{*}-0.03$ & $0.16^{*}$ & $0.05^{* *}$ & 0.03 & $0.02 * *$ & $-0.11 *$ & $0.12 * *$ & $0.10^{*}$ & $0.03 *$ & 0.17 & 0.12 & 1 & & & & \\
\hline 17. Average loan & 602 & 1052 & $-0.10^{* *}$ & $*-0.18 * *$ & -0.11 & $-0.01 *$ & 0.02 & 0.1 & 0.12 & $-0.07 *$ & -0.01 & 0.06 & 0.02 & $-0.03 *$ & 0.11 & 0.21 & 0.15 & $0.16^{*}$ & 1 & & & \\
\hline 18. Assets & 6.425 & 0.588 & $0.11^{* *}$ & $0.14 * *$ & -0.01 & -0.02 & 0.02 & $-0.11 *$ & 0.02 & 0.05 & $0.23 *$ & 0.08 & 0.19 & $0.21 * *$ & $-0,25^{*}$ & 0.16 & $0.19^{*}$ & 0.21 & 0.25 & 1 & & \\
\hline 19. Туре & 0.399 & 0.473 & -0.05 & -0.03 & 0.02 & 0.09 & -0.03 & $-0.21 *$ & -0.11 & $-0.06^{* *}$ & 0.13 & $-0.07 *$ & -0.13 & $0.37^{*}$ & $0.13 *$ & -0.11 & $0.12 *$ & $0.11^{*}$ & 0.26 & 0.17 & 1 & \\
\hline 20. MFB age & 0.866 & 0.315 & $0.08^{*}$ & 0.12 & 0.03 & 0.02 & 0.01 & 0.02 & $0.08^{*}$ & 0.01 & -0.17 & -0.20 & -0.11 & $0.15^{*}$ & -0.10 & -0.14 & -0.12 & 0.15 & -0.11 & 0.18 & $0.12 *$ & 1 \\
\hline
\end{tabular}

Note: Significance level: two tails: ${ }^{* *} \mathrm{p}<0.01,{ }^{*} \mathrm{p}<0.05$. Regional dummies are not included. 
Table 3

Results of Random Effect Model GLS with ROA as the Dependent Variable

\begin{tabular}{|c|c|c|c|c|}
\hline ROA & Model 1 & Model 2 & Model 3 & Model 4 \\
\hline Constant & $\begin{array}{l}0.168 \\
0.619\end{array}$ & $\begin{array}{l}0.124 \\
(0.062)\end{array}$ & $\begin{array}{l}0.226 \\
(0.086)\end{array}$ & $\begin{array}{l}0.254 \\
(0.036)\end{array}$ \\
\hline MFB global lang. French & $\begin{array}{l}0.025 * * * \\
(0.002)\end{array}$ & & & \\
\hline MFB global lang. Spanish & $\begin{array}{l}0.056^{* * *} \\
(0.002)\end{array}$ & & & \\
\hline MFB global lang. English & $\begin{array}{l}0.123 * * * \\
(0.001)\end{array}$ & & & \\
\hline Shared global language & & $\begin{array}{l}0.043 * * * \\
(0.015)\end{array}$ & $\begin{array}{l}0.036 * * \\
(0.016)\end{array}$ & $\begin{array}{l}0.028 * * \\
(0.022)\end{array}$ \\
\hline Shared global lang. English & & $\begin{array}{l}0.232 * * * \\
(0.012)\end{array}$ & & \\
\hline Shared global lang. French & & $\begin{array}{l}0.026 \\
(0.045)\end{array}$ & & \\
\hline Shared global lang. Spanish & & $\begin{array}{l}0.122 * \\
(0.048)\end{array}$ & & \\
\hline $\mathrm{LD}^{f}$ & & & $\begin{array}{l}-0.522^{* *} \\
(0.039)\end{array}$ & \\
\hline L1MFe & & & & $\begin{array}{l}-0.036 * * \\
(0.015)\end{array}$ \\
\hline L1IPe & & & & $\begin{array}{l}-0.057^{* *} \\
(0.014)\end{array}$ \\
\hline Institutional distance & $\begin{array}{l}-0.020 * * \\
(0.012)\end{array}$ & $\begin{array}{l}-0.013 * * \\
(0.005)\end{array}$ & $\begin{array}{l}-0.032 * * \\
(0.001)\end{array}$ & $\begin{array}{l}-0.021 * * \\
(0.002)\end{array}$ \\
\hline Cultural distance & $\begin{array}{l}-0.115 \\
(0.012)\end{array}$ & $\begin{array}{l}-0.187 \\
(0.042)\end{array}$ & $\begin{array}{l}-0.192 \\
(0.028)\end{array}$ & $\begin{array}{l}-0.180 \\
(0.025)\end{array}$ \\
\hline Colony & $\begin{array}{l}0.016^{*} \\
(0.081)\end{array}$ & $\begin{array}{l}0.025 * \\
(0.021)\end{array}$ & $\begin{array}{l}0.026^{*} \\
(0.033)\end{array}$ & $\begin{array}{l}0.015 * \\
(0.083)\end{array}$ \\
\hline Geographical distance & $\begin{array}{l}-0.438 \\
(0.036)\end{array}$ & $\begin{array}{l}-0.512 \\
(0.054)\end{array}$ & $\begin{array}{l}-0.451 \\
(0.039)\end{array}$ & $\begin{array}{l}-0.475 \\
(0.032)\end{array}$ \\
\hline Region Africa & $\begin{array}{l}0.005 \\
(0.001)\end{array}$ & $\begin{array}{l}0.007 \\
(0.002)\end{array}$ & $\begin{array}{l}0.010 \\
(0.004)\end{array}$ & $\begin{array}{l}0.006 \\
(0.003)\end{array}$ \\
\hline Region Asia & $\begin{array}{l}-0.004 \\
(0.001)\end{array}$ & $\begin{array}{l}-0.003 \\
(0.000)\end{array}$ & $\begin{array}{l}-0.001 \\
(0.000)\end{array}$ & $\begin{array}{l}-0.005 \\
(0.001)\end{array}$ \\
\hline Region EECA & $\begin{array}{l}-0.016 \\
(0.002)\end{array}$ & $\begin{array}{l}-0.015 \\
(0.005)\end{array}$ & $\begin{array}{l}-0.021 \\
(0.007)\end{array}$ & $\begin{array}{l}-0.012 \\
(0.006)\end{array}$ \\
\hline Region Latin America & $\begin{array}{l}-0.003 \\
(0.001)\end{array}$ & $\begin{array}{l}-0.001 \\
(0.001)\end{array}$ & $\begin{array}{l}-0.006 \\
(0.003)\end{array}$ & $\begin{array}{l}-0.004 \\
(0.002)\end{array}$ \\
\hline Region MENA & $\begin{array}{l}-0.027 \\
(0.009)\end{array}$ & $\begin{array}{l}-0.018 \\
(0.008)\end{array}$ & $\begin{array}{l}-0.022 \\
(0.011)\end{array}$ & $\begin{array}{l}-0.019 \\
(0.009)\end{array}$ \\
\hline Region Europe & $\begin{array}{l}0.015 \\
(0.008)\end{array}$ & $\begin{array}{l}0.014 \\
(0.004)\end{array}$ & $\begin{array}{l}0.013 \\
(0.007)\end{array}$ & $\begin{array}{l}0.016 \\
(0.006)\end{array}$ \\
\hline Region North America & $\begin{array}{l}0.025 \\
(0.013)\end{array}$ & $\begin{array}{l}0.021 \\
(0.009)\end{array}$ & $\begin{array}{l}0.023 \\
(0.011)\end{array}$ & $\begin{array}{l}0.022 \\
(0.012)\end{array}$ \\
\hline International MFB & $\begin{array}{l}-0.006 \\
(0.014)\end{array}$ & $\begin{array}{l}0.001 \\
(0.018)\end{array}$ & $\begin{array}{l}0.006 \\
(0.016)\end{array}$ & $\begin{array}{l}-0.004 \\
(0.012)\end{array}$ \\
\hline Regulation & $\begin{array}{l}-0.006 \\
(0.001)\end{array}$ & $\begin{array}{l}-0.135 * \\
(0.044)\end{array}$ & $\begin{array}{l}-0.123 * * \\
(0.018)\end{array}$ & $\begin{array}{l}-0.082 \\
(0.013)\end{array}$ \\
\hline Type & $\begin{array}{l}-0.005 \\
(0.518)\end{array}$ & $\begin{array}{l}0.002 \\
(0.017)\end{array}$ & $\begin{array}{l}-0.004 \\
(0.015)\end{array}$ & $\begin{array}{l}-0.019 \\
(0.016)\end{array}$ \\
\hline Assets & $\begin{array}{l}0.008 * * \\
(0.001)\end{array}$ & $\begin{array}{l}0.005 * * \\
(0.005)\end{array}$ & $\begin{array}{l}0.005 * * \\
(0.002)\end{array}$ & $\begin{array}{l}0.009 * * \\
(0.000)\end{array}$ \\
\hline
\end{tabular}




\begin{tabular}{lllll} 
Average loan & 0.002 & 0.001 & 0.015 & 0.006 \\
& $(0.014)$ & $(0.002)$ & $(0.000)$ & $(0.001)$ \\
MFB age & $0.005^{* *}$ & $0.001^{* *}$ & $0.006^{* *}$ & $0.004^{* *}$ \\
& $(0.002)$ & $(0.000)$ & $(0.000)$ & $(0.000)$ \\
Overall R-square & 0.35 & 0.29 & 0.31 & 0.34 \\
Wald chi-square & $162.68^{* * *}$ & $134.45^{* * *}$ & $145.29 * * *$ & $155.56^{* * *}$ \\
Observations & 1326 & 1228 & 1184 & 1176 \\
\hline Note: $* * * \mathrm{p}<0.001 ; * * \mathrm{p}<0.01 ; * \mathrm{p}<0.05$ and standard errors in brackets. Model 1 tests the effect on an MFB's \\
financial performance if a global language holds an official status in the MFB's country. Model 2 tests the effect \\
on an MFB's financial performance if the MFB's country and the international partner's country share at least one \\
global language. Model 3 tests the linguistic distance (LD') effect on an MFB's financial performance. Model 4 \\
accounts for the financial performance effect of the linguistic distance of the MFB's country's major language and \\
the partner's country's major language to English.
\end{tabular}


Table 4

Results of Random Effect Model GLS with OSS as the Dependent Variable

\begin{tabular}{|c|c|c|c|c|}
\hline OSS & Model 1 & Model 2 & Model 3 & Model 4 \\
\hline Constant & $\begin{array}{l}0.581 \\
0.619\end{array}$ & $\begin{array}{l}0.214 \\
(0.062)\end{array}$ & $\begin{array}{l}0.426 \\
(0.086)\end{array}$ & $\begin{array}{l}0.514 \\
(0.036)\end{array}$ \\
\hline MFB global lang. French & $\begin{array}{l}0.025 * * * \\
(0.002)\end{array}$ & & & \\
\hline MFB global lang. Spanish & $\begin{array}{l}0.056^{* * *} \\
(0.002)\end{array}$ & & & \\
\hline MFB global lang. English & $\begin{array}{l}0.123 * * * \\
(0.001)\end{array}$ & & & \\
\hline Shared global language & & $\begin{array}{l}0.023 * * * \\
(0.019)\end{array}$ & $\begin{array}{l}0.019 * * \\
(0.012)\end{array}$ & $\begin{array}{l}0.022 * * \\
(0.015)\end{array}$ \\
\hline Shared global lang. English & & $\begin{array}{l}0.228 * * * \\
(0.034)\end{array}$ & & \\
\hline Shared global lang. French & & $\begin{array}{l}0.047 \\
(0.051)\end{array}$ & & \\
\hline Shared global lang. Spanish & & $\begin{array}{l}0.108 * \\
(0.044)\end{array}$ & & \\
\hline $\mathrm{LD}^{f}$ & & & $\begin{array}{l}-0.422^{* *} \\
(0.032)\end{array}$ & \\
\hline L1MFe & & & & $\begin{array}{l}-0.014 * * \\
(0.011)\end{array}$ \\
\hline L1IPe & & & & $\begin{array}{l}-0.047^{* *} \\
(0.016)\end{array}$ \\
\hline Institutional distance & $\begin{array}{l}-0.015 * * \\
(0.007)\end{array}$ & $\begin{array}{l}-0.023 * * \\
(0.015)\end{array}$ & $\begin{array}{l}-0.022 * * \\
(0.011)\end{array}$ & $\begin{array}{l}-0.027^{* *} \\
(0.012)\end{array}$ \\
\hline Cultural distance & $\begin{array}{l}-0.125 \\
(0.018)\end{array}$ & $\begin{array}{l}-0.167 \\
(0.022)\end{array}$ & $\begin{array}{l}-0.173 \\
(0.019)\end{array}$ & $\begin{array}{l}-0.184 \\
(0.024)\end{array}$ \\
\hline Colony & $\begin{array}{l}0.015 * \\
(0.062)\end{array}$ & $\begin{array}{l}0.024 * \\
(0.022)\end{array}$ & $\begin{array}{l}0.023 * \\
(0.023)\end{array}$ & $\begin{array}{l}0.018 * \\
(0.053)\end{array}$ \\
\hline Geographical distance & $\begin{array}{l}-0.381 \\
(0.025)\end{array}$ & $\begin{array}{l}-0.421 \\
(0.047)\end{array}$ & $\begin{array}{l}-0.541 \\
(0.029)\end{array}$ & $\begin{array}{l}-0.486 \\
(0.036)\end{array}$ \\
\hline Region Africa & $\begin{array}{l}0.006 \\
(0.001)\end{array}$ & $\begin{array}{l}0.005 \\
(0.002)\end{array}$ & $\begin{array}{l}0.009 \\
(0.003)\end{array}$ & $\begin{array}{l}0.011 \\
(0.006)\end{array}$ \\
\hline Region Asia & $\begin{array}{l}0.005 \\
(0.001)\end{array}$ & $\begin{array}{l}0.003 \\
(0.000)\end{array}$ & $\begin{array}{l}0.002 \\
(0.000)\end{array}$ & $\begin{array}{l}0.004 \\
(0.001)\end{array}$ \\
\hline Region EECA & $\begin{array}{l}-0.012 \\
(0.003)\end{array}$ & $\begin{array}{l}-0.013 \\
(0.007)\end{array}$ & $\begin{array}{l}-0.011 \\
(0.009)\end{array}$ & $\begin{array}{l}-0.014 \\
(0.005)\end{array}$ \\
\hline Region Latin America & $\begin{array}{l}-0.003 \\
(0.001)\end{array}$ & $\begin{array}{l}-0.001 \\
(0.002)\end{array}$ & $\begin{array}{l}-0.005 \\
(0.001)\end{array}$ & $\begin{array}{l}-0.007 \\
(0.002)\end{array}$ \\
\hline Region MENA & $\begin{array}{l}-0.028 \\
(0.009)\end{array}$ & $\begin{array}{l}-0.017 \\
(0.006)\end{array}$ & $\begin{array}{l}-0.019 \\
(0.010)\end{array}$ & $\begin{array}{l}-0.020 \\
(0.009)\end{array}$ \\
\hline Region Europe & $\begin{array}{l}0.016 \\
(0.008)\end{array}$ & $\begin{array}{l}0.015 \\
(0.004)\end{array}$ & $\begin{array}{l}0.011 \\
(0.006)\end{array}$ & $\begin{array}{l}0.012 \\
(0.007)\end{array}$ \\
\hline Region North America & $\begin{array}{l}0.021 \\
(0.011)\end{array}$ & $\begin{array}{l}0.018 \\
(0.009)\end{array}$ & $\begin{array}{l}0.019 \\
(0.012)\end{array}$ & $\begin{array}{l}0.020 \\
(0.011)\end{array}$ \\
\hline International MFB & $\begin{array}{l}-0.004 \\
(0.004)\end{array}$ & $\begin{array}{l}0.001 \\
(0.012)\end{array}$ & $\begin{array}{l}0.003 \\
(0.015)\end{array}$ & $\begin{array}{l}-0.005 \\
(0.013)\end{array}$ \\
\hline Regulation & $\begin{array}{l}-0.009 \\
(0.077)\end{array}$ & $\begin{array}{l}-0.315 * \\
(0.014)\end{array}$ & $\begin{array}{l}-0.131^{* *} \\
(0.015)\end{array}$ & $\begin{array}{l}-0.073 \\
(0.019)\end{array}$ \\
\hline Type & $\begin{array}{l}-0.004 \\
(0.005)\end{array}$ & $\begin{array}{l}0.001 \\
(0.011)\end{array}$ & $\begin{array}{l}-0.004 \\
(0.013)\end{array}$ & $\begin{array}{l}-0.018 \\
(0.014)\end{array}$ \\
\hline Assets & $\begin{array}{l}0.004 * * \\
(0.001)\end{array}$ & $\begin{array}{l}0.005 * * \\
(0.004)\end{array}$ & $\begin{array}{l}0.006 * * \\
(0.002)\end{array}$ & $\begin{array}{l}0.007 * * \\
(0.000)\end{array}$ \\
\hline
\end{tabular}




\begin{tabular}{lllll} 
Average loan & 0.021 & 0.002 & 0.016 & 0.008 \\
MFB age & $(0.013)$ & $(0.002)$ & $(0.000)$ & $(0.001)$ \\
& $0.005^{* *}$ & $0.002 * *$ & $0.003^{* *}$ & $0.004^{* *}$ \\
Overall R-square & $(0.002)$ & $(0.000)$ & $(0.000)$ & $(0.000)$ \\
Wald chi-square & 0.29 & 0.28 & 0.30 & 0.33 \\
Observations & $142.88^{* *}$ & $128.45^{* *}$ & $143.71 * *$ & $152.14^{* *}$ \\
\hline
\end{tabular}

Note: $* * * \mathrm{p}<0.001 ; * * \mathrm{p}<0.01 ; * \mathrm{p}<0.05$ and standard errors in brackets. Model 1 tests the effect on an MFB's financial performance if a global language holds an official status in the MFB's country. Model 2 tests the effect on an MFB's financial performance if the MFB's country and the international partner's country share at least one global language. Model 3 tests the linguistic distance $\left(\mathrm{LD}^{f}\right)$ effect on an MFB's financial performance. Model 4 accounts for the financial performance effect of the linguistic distance of the MFB's country's major language and the partner's country's major language to English. 
Appendix A. Descriptive Statistics on International Partner Types

\begin{tabular}{lccccc}
\hline & Mean & Std. & Min & Max & Obs. \\
\hline International initiator & 0.377 & 0.485 & 0.000 & 1.000 & 290 \\
International commercial debt & 0.406 & 0.491 & 0.000 & 1.000 & 260 \\
International subsidized debt & 0.514 & 0.500 & 0.000 & 1.000 & 260 \\
International director & 0.558 & 1.201 & 0.000 & 6.000 & 220 \\
International network member & 0.328 & 0.471 & 0.000 & 1.000 & 295 \\
\hline
\end{tabular}

A global survey of 405 MFBs in 74 countries shows that as many as $38 \%$ of the MFBs have an international initiator, $41 \%$ have international commercial debt, $51 \%$ have international subsidized debt, $24 \%$ have at least one international director, and $33 \%$ are members of a recognized international network. 
Appendix B. International Partners' Country of Origin, Geographical Region, and Major Languages

\begin{tabular}{|c|c|c|c|c|c|c|c|c|c|c|}
\hline \multirow[b]{2}{*}{ Country } & \multirow[b]{2}{*}{ Region } & \multicolumn{3}{|c|}{ First major language } & \multicolumn{3}{|c|}{ Second major language } & \multicolumn{3}{|c|}{ Third major language } \\
\hline & & Language & Users & Status & Language & Users & Status & Language & Users & Status \\
\hline Belgium & Europe & French & $75.49 \%$ & & Dutch & $50.09 \%$ & & English & $34.60 \%$ & \\
\hline Canada & North America & English & $75.09 \%$ & & French & $28.44 \%$ & & & & \\
\hline Cayman Islands & North America & English & $89.29 \%$ & & Haitian Creole & $37.14 \%$ & & & & \\
\hline France & Europe & French & $95.01 \%$ & & English & $38.06 \%$ & & & & \\
\hline Germany & Europe & Standard German & $96.22 \%$ & & English & $55.87 \%$ & & & & \\
\hline India & Other & Hindi & $29.18 \%$ & & English & $15.47 \%$ & $\mathrm{X}$ & & & \\
\hline Italy & Europe & Italian & $94.93 \%$ & & English & $33.28 \%$ & & & & \\
\hline Luxembourg & Europe & French & $87.48 \%$ & $\mathrm{x}$ & Standard German & $64.06 \%$ & $\mathrm{X}$ & Luxembourgish & $55.73 \%$ & \\
\hline Netherlands & Europe & Dutch & $93.15 \%$ & & English & $89.00 \%$ & & Standard German & $70.01 \%$ & \\
\hline Nicaragua & North America & Spanish & $99.66 \%$ & & & & & & & \\
\hline Norway & Europe & Norwegian & $89.09 \%$ & & & & & & & \\
\hline Peru & Other & Spanish & $85.58 \%$ & & & & & & & \\
\hline Philippines & Other & Filipino & $44.69 \%$ & & English & $39.74 \%$ & $\mathrm{X}$ & Tagalog & $21.35 \%$ & \\
\hline Poland & Europe & Polish & $96.99 \%$ & & English & $33.14 \%$ & & & & \\
\hline South Africa & Other & Zulu & $50.10 \%$ & & Xhosa & $35.14 \%$ & & Afrikaans & $31.49 \%$ & \\
\hline Switzerland & Europe & French & $64.35 \%$ & & Swiss German & $54.82 \%$ & & & & \\
\hline United Kingdom & Europe & English & $90.06 \%$ & & & & & & & \\
\hline United States & North America & English & $77.98 \%$ & & & & & & & \\
\hline
\end{tabular}

Note: The table displays up to three major languages in the partners' countries. Users represents the fraction of the country's population that speaks the respective language (regardless of whether as a native speaker or not). The major languages are labeled first, second, and third in accordance with the number of users. A language is deemed major if at least $20 \%$ of the country's population uses it as their first or second language. In addition, a language is deemed major if it holds the official status of a statutory working language in that country, which is indicated by the Status column (see Dow \& Karunaratna, 2006). 
Appendix C. MFB's Country of Origin, Geographical Region, and Major Languages

\begin{tabular}{|c|c|c|c|c|c|c|c|c|c|}
\hline & & First major la & & Second $\mathrm{n}$ & guage & & Third maj & uage & \\
\hline Country & Region & Language & Status & Language & Users & Status & Language & Users & Status \\
\hline Albania & Other & Tosk Albanian & $53.62 \%$ & Gheg Albanian & $40.98 \%$ & & & & \\
\hline Argentina & Latin America & Spanish & $95.93 \%$ & & & & & & \\
\hline Armenia & Other & Armenian & $96.86 \%$ & & & & & & \\
\hline Azerbaijan & Other & North Azerbaijani & $87.61 \%$ & & & & & & \\
\hline Benin & Africa & French & $33.02 \%$ & & & & & & \\
\hline Bolivia & Latin America & Spanish & $87.46 \%$ & & & & & & \\
\hline Bosnia and Herzegovina & Other & Bosnian & $29.40 \%$ & Serbian & $22.31 \%$ & & & & \\
\hline Brazil & Latin America & Portuguese & $91.55 \%$ & & & & & & \\
\hline Bulgaria & EECA & Bulgarian & $96.63 \%$ & English & $25.46 \%$ & & Russian & $23.62 \%$ & \\
\hline Burkina Faso & Africa & Mòoré & $36.71 \%$ & French & $21.59 \%$ & & Jula & $20.87 \%$ & \\
\hline Burundi & Africa & Rundi & $93.09 \%$ & & & & & & \\
\hline Cambodia & Asia & Central Khmer & $89.23 \%$ & & & & & & \\
\hline Cameroon & Africa & French & $36.15 \%$ & English & $32.98 \%$ & & & & \\
\hline Chad & Africa & French & $14.52 \%$ & Ngambay & $11.81 \%$ & & Chadian Spoken Arabic & $11.81 \%$ & \\
\hline Chile & Latin America & Spanish & $99.55 \%$ & & & & & & \\
\hline China & Asia & Mandarin Chinese & $78.03 \%$ & & & & & & \\
\hline Colombia & Latin America & Spanish & $99.91 \%$ & & & & & & \\
\hline Croatia & EECA & Croatian & $94.06 \%$ & Standard German & $32.77 \%$ & & & & \\
\hline Dominican Republic & Latin America & Spanish & $90.68 \%$ & & & & & & \\
\hline Ecuador & Latin America & Spanish & $97.71 \%$ & & & & & & \\
\hline Egypt & MENA & Egyptian Spoken Arabic & $63.74 \%$ & Sa'idi Spoken Arabic & $22.94 \%$ & & & & \\
\hline El Salvador & Latin America & Spanish & $99.09 \%$ & & & & & & \\
\hline Ethiopia & Africa & Amharic & $29.11 \%$ & & & & & & \\
\hline Gambia & Africa & Mandinka & $24.49 \%$ & & & & & & \\
\hline Georgia & Other & Georgian & $86.59 \%$ & & & & & & \\
\hline Ghana & Africa & Akan & $33.65 \%$ & & & & & & \\
\hline Guatemala & Latin America & Spanish & $86.39 \%$ & & & & & & \\
\hline Guinea & Africa & Eastern Maninkakan & $28.22 \%$ & French & $26.06 \%$ & & Pular & $23.99 \%$ & \\
\hline Haiti & Latin America & Haitian Creole & $66.78 \%$ & French & $41.93 \%$ & $\mathrm{X}$ & & & \\
\hline Honduras & Latin America & Spanish & $98.94 \%$ & & & & & & \\
\hline India & Asia & Hindi & $29.18 \%$ & English & $15.47 \%$ & $\mathrm{X}$ & & & \\
\hline Indonesia & Asia & Indonesian & $77.43 \%$ & Javanese & $33.00 \%$ & & & & \\
\hline Jordan & MENA & South Levantine Spoken Arabic & $47.27 \%$ & & & & & & \\
\hline Kazakhstan & EECA & Russian & $107.52 \%$ & Kazakh & $56.62 \%$ & & & & \\
\hline Kenya & Africa & Swahili & $36.17 \%$ & & & & & & \\
\hline Kyrgyzstan & EECA & Kyrgyz & $65.65 \%$ & & & & & & \\
\hline Madagascar & Africa & Plateau Malagasy & $34.43 \%$ & French & $21.01 \%$ & & & & \\
\hline Malawi & Africa & Chichewa & $37.76 \%$ & English & $3.23 \%$ & $\mathrm{X}$ & & & \\
\hline Maldives & Asia & Maldivian & $84.22 \%$ & & & & & & \\
\hline Mali & Africa & Bamanankan & $82.57 \%$ & & & & & & \\
\hline Mauritania & Africa & Hassaniyya & $88.78 \%$ & & & & & & \\
\hline
\end{tabular}




\begin{tabular}{|c|c|c|c|c|c|c|c|c|c|c|}
\hline Mexico & Latin America & Spanish & $95.67 \%$ & & & & & & & \\
\hline Mongolia & Asia & Halh Mongolian & $86.87 \%$ & & & & & & & \\
\hline Montenegro & Other & Serbian & $81.31 \%$ & & & & & & & \\
\hline Morocco & MENA & Moroccan Spoken Arabic & $73.69 \%$ & & French & $30.84 \%$ & & & & \\
\hline Mozambique & Africa & Portuguese & $32.78 \%$ & & & & & & & \\
\hline Nepal & Asia & Nepali & $43.66 \%$ & & English & $24.86 \%$ & & & & \\
\hline Nicaragua & Latin America & Spanish & $99.66 \%$ & & & & & & & \\
\hline Niger & Africa & Hausa & $44.77 \%$ & & & & & & & \\
\hline Nigeria & Africa & English & $33.05 \%$ & & & & & & & \\
\hline Peru & Latin America & Spanish & $85.58 \%$ & & & & & & & \\
\hline Philippines & Asia & Filipino & $44.69 \%$ & & English & $39.74 \%$ & $\mathrm{X}$ & Tagalog & $21.35 \%$ & \\
\hline Romania & EECA & Romanian & $99.94 \%$ & & English & $33.35 \%$ & & & & \\
\hline Russian Federation & EECA & Russian & $95.47 \%$ & & & & & & & \\
\hline Rwanda & Africa & Kinyarwanda & $91.30 \%$ & & French & $5.48 \%$ & $\mathrm{X}$ & English & $0.17 \%$ & $\mathrm{X}$ \\
\hline Senegal & Africa & Wolof & $38.57 \%$ & & French & $29.00 \%$ & & Pulaar & $25.54 \%$ & \\
\hline Serbia & EECA & Serbian & $88.93 \%$ & & & & & & & \\
\hline South Africa & Africa & Zulu & $50.10 \%$ & & Xhosa & $35.14 \%$ & & Afrikaans & $31.49 \%$ & \\
\hline Sri Lanka & Asia & Sinhala & $79.31 \%$ & & Tamil & $24.58 \%$ & & & & \\
\hline Tajikistan & EECA & Tajiki & $76.90 \%$ & & & & & & & \\
\hline Tanzania & Africa & Swahili & $92.07 \%$ & & & & & & & \\
\hline Togo & Africa & French & $36.18 \%$ & & & & & & & \\
\hline Trinidad and Tobago & Latin America & English & $97.52 \%$ & & Trinidadian Creole English & $75.02 \%$ & & Tobagonian Creole English & $22.51 \%$ & \\
\hline Tunisia & MENA & Tunisian Spoken Arabic & $98.33 \%$ & & French & $53.73 \%$ & & & & \\
\hline Uganda & Africa & Swahili & $91.94 \%$ & $\mathrm{X}$ & & & & & & \\
\hline Viet Nam & Asia & Vietnamese & $72.55 \%$ & & & & & & & \\
\hline Zambia & Africa & Bemba & $29.10 \%$ & & & & & & & \\
\hline
\end{tabular}

Note: The table displays up to three major languages in the MFB countries. Users represents the fraction of the country's population that speaks the respective language (regardless of whether as a native speaker or not). The major languages are labeled first, second, and third in accordance with the number of users. A language is deemed major if at least $20 \%$ of the country's population uses it as their first or second language (except for Chad, where we applied a 10\% threshold; see Dow \& Karunaratna, 2006). In addition, a language is deemed major if it holds the official status of a statutory working language in that country, which is indicated by the Status column. 
Appendix D. Robustness Test. Results of Random Effect Model GLS with ROE as the Dependent Variable

\begin{tabular}{|c|c|c|c|c|}
\hline ROE & Model 1 & Model 2 & Model 3 & Model 4 \\
\hline Constant & $\begin{array}{l}0.617 \\
(0.519)\end{array}$ & $\begin{array}{l}0.412 \\
(0.028)\end{array}$ & $\begin{array}{l}0.726 \\
(0.075)\end{array}$ & $\begin{array}{l}0.544 \\
(0.063)\end{array}$ \\
\hline MFB global lang. French & $\begin{array}{l}0.056^{* *} \\
(0.008)\end{array}$ & & & \\
\hline MFB global lang. Spanish & $\begin{array}{l}0.076^{* * *} \\
(0.002)\end{array}$ & & & \\
\hline MFB global lang. English & $\begin{array}{l}0.203 * * * \\
(0.012)\end{array}$ & & & \\
\hline Shared global language & & $\begin{array}{l}0.038 * * * \\
(0.011)\end{array}$ & $\begin{array}{l}0.053 * * \\
(0.015)\end{array}$ & $\begin{array}{l}0.034 * * * \\
(0.012)\end{array}$ \\
\hline Shared global lang. English & & $\begin{array}{l}0.259 * * * \\
(0.042)\end{array}$ & & \\
\hline Shared global lang. French & & $\begin{array}{l}0.076 \\
(0.061)\end{array}$ & & \\
\hline Shared global lang. Spanish & & $\begin{array}{l}0.119 \\
(0.034)\end{array}$ & & \\
\hline $\mathrm{LD}^{f}$ & & & $\begin{array}{l}-0.242 * * \\
(0.022)\end{array}$ & \\
\hline L1MFe & & & & $\begin{array}{l}-0.018^{* *} \\
(0.012)\end{array}$ \\
\hline L1IPe & & & & $\begin{array}{l}-0.077^{* *} \\
(0.015)\end{array}$ \\
\hline Institutional distance & $\begin{array}{l}-0.020 * \\
(0.005)\end{array}$ & $\begin{array}{l}-0.025^{*} \\
(0.009)\end{array}$ & $\begin{array}{l}-0.023^{*} \\
(0.010)\end{array}$ & $\begin{array}{l}-0.032 * \\
(0.020)\end{array}$ \\
\hline Cultural distance & $\begin{array}{l}-0.251 \\
(0.032)\end{array}$ & $\begin{array}{l}-0.175 \\
(0.032)\end{array}$ & $\begin{array}{l}-0.182 \\
(0.020)\end{array}$ & $\begin{array}{l}-0.197 \\
(0.034)\end{array}$ \\
\hline Colony & $\begin{array}{l}0.018^{*} \\
(0.019)\end{array}$ & $\begin{array}{l}0.014^{*} \\
(0.021)\end{array}$ & $\begin{array}{l}0.033^{*} \\
(0.063)\end{array}$ & $\begin{array}{l}0.021 * \\
(0.033)\end{array}$ \\
\hline Geographical distance & $\begin{array}{l}-0.372 \\
(0.023)\end{array}$ & $\begin{array}{l}-0.414 \\
(0.028)\end{array}$ & $\begin{array}{l}-0.451 \\
(0.030)\end{array}$ & $\begin{array}{l}-0.458 \\
(0.035)\end{array}$ \\
\hline Region Africa & $\begin{array}{l}0.008 \\
(0.003)\end{array}$ & $\begin{array}{l}0.009 \\
(0.004)\end{array}$ & $\begin{array}{l}0.007 \\
(0.002)\end{array}$ & $\begin{array}{l}0.010 \\
(0.005)\end{array}$ \\
\hline Region Asia & $\begin{array}{l}0.003 \\
(0.001)\end{array}$ & $\begin{array}{l}0.004 \\
(0.000)\end{array}$ & $\begin{array}{l}0.001 \\
(0.000)\end{array}$ & $\begin{array}{l}0.004 \\
(0.001)\end{array}$ \\
\hline Region EECA & $\begin{array}{l}-0.015 \\
(0.003)\end{array}$ & $\begin{array}{l}-0.016 \\
(0.005)\end{array}$ & $\begin{array}{l}-0.012 \\
(0.008)\end{array}$ & $\begin{array}{l}-0.016 \\
(0.004)\end{array}$ \\
\hline Region Latin America & $\begin{array}{l}-0.005 \\
(0.001)\end{array}$ & $\begin{array}{l}-0.002 \\
(0.000)\end{array}$ & $\begin{array}{l}-0.007 \\
(0.001)\end{array}$ & $\begin{array}{l}-0.009 \\
(0.002)\end{array}$ \\
\hline Region MENA & $\begin{array}{l}-0.027 \\
(0.010)\end{array}$ & $\begin{array}{l}-0.012 \\
(0.008)\end{array}$ & $\begin{array}{l}-0.019 \\
(0.007)\end{array}$ & $\begin{array}{l}-0.020 \\
(0.009)\end{array}$ \\
\hline Region Europe & $\begin{array}{l}0.017 \\
(0.007)\end{array}$ & $\begin{array}{l}0.016 \\
(0.004)\end{array}$ & $\begin{array}{l}0.012 \\
(0.003)\end{array}$ & $\begin{array}{l}0.014 \\
(0.008)\end{array}$ \\
\hline Region North America & $\begin{array}{l}0.022 \\
(0.013)\end{array}$ & $\begin{array}{l}0.019 \\
(0.010)\end{array}$ & $\begin{array}{l}0.021 \\
(0.013)\end{array}$ & $\begin{array}{l}0.018 \\
(0.009)\end{array}$ \\
\hline International MFB & $\begin{array}{l}-0.002 \\
(0.000)\end{array}$ & $\begin{array}{l}0.001 \\
(0.010)\end{array}$ & $\begin{array}{l}0.005^{*} \\
(0.012)\end{array}$ & $\begin{array}{l}-0.008^{*} \\
(0.013)\end{array}$ \\
\hline Regulation & $\begin{array}{l}-0.008 \\
(0.073)\end{array}$ & $\begin{array}{l}-0.215^{*} \\
(0.015)\end{array}$ & $\begin{array}{l}-0.123^{* *} \\
(0.016)\end{array}$ & $\begin{array}{l}-0.043 \\
(0.018)\end{array}$ \\
\hline Type & $\begin{array}{l}-0.003 \\
(0.004)\end{array}$ & $\begin{array}{l}0.002 \\
(0.018)\end{array}$ & $\begin{array}{l}-0.006 \\
(0.011)\end{array}$ & $\begin{array}{l}-0.015 \\
(0.013)\end{array}$ \\
\hline Assets & $\begin{array}{l}0.009 * * \\
(0.004)\end{array}$ & $\begin{array}{l}0.004 * * \\
(0.002)\end{array}$ & $\begin{array}{l}0.005 * * \\
(0.003)\end{array}$ & $\begin{array}{l}0.003 * * \\
(0.000)\end{array}$ \\
\hline Average loan & 0.021 & 0.003 & 0.014 & $0.009 *$ \\
\hline
\end{tabular}




\begin{tabular}{lllll} 
& $(0.011)$ & $(0.000)$ & $(0.001)$ & $(0.002)$ \\
MFB age & $0.004 * * *$ & $0.003 * * *$ & $0.005^{* * *}$ & $0.008^{* * *}$ \\
Overall R-square & $(0.002)$ & $(0.001)$ & $(0.000)$ & $(0.001)$ \\
Wald chi-square & 0.28 & 0.27 & 0.30 & 0.32 \\
Observations & $138.98^{* *}$ & $125.53 * *$ & $142.12 * *$ & $158.78^{* *}$ \\
\hline
\end{tabular}

Note: $* * * \mathrm{p}<0.001 ; * * \mathrm{p}<0.01 ; * \mathrm{p}<0.05$ and standard errors in brackets. Model 1 tests the effect on an MFB's financial performance if a global language holds an official status in the MFB's country. Model 2 tests the effect on an MFB's financial performance if the MFB's country and the international partner's country share at least one global language. Model 3 tests the linguistic distance $\left(\mathrm{LD}^{f}\right)$ effect on an MFB's financial performance. Model 4 accounts for the financial performance effect of the linguistic distance of the MFB's country's major language and the partner's country's major language to English.

Fig. 1. Key Stakeholders in the International Microfinance Industry and the Effect of Language Use

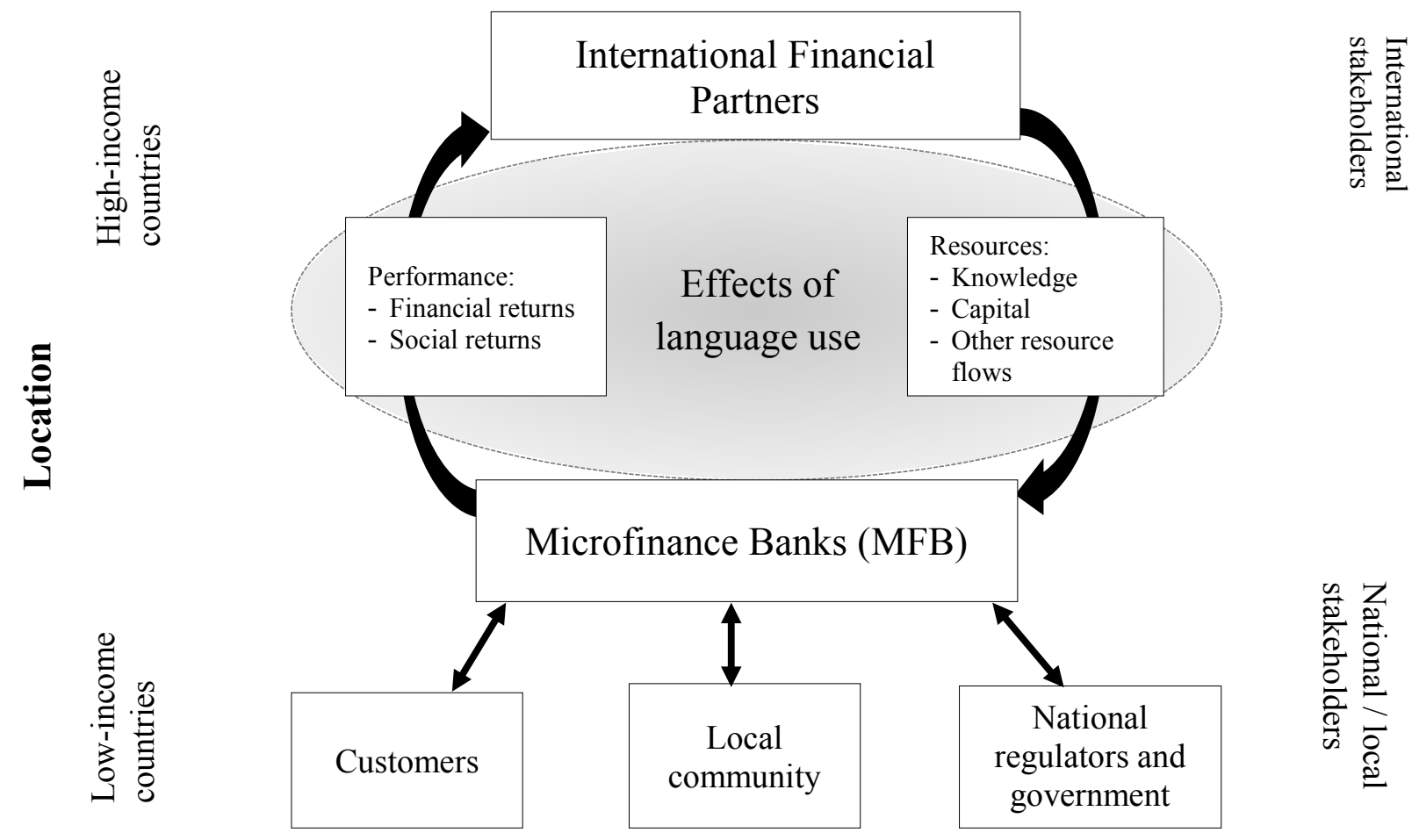

